\title{
Machining Performance Investigation of AISI 304 Austenitic Stainless Steel under Different Turning Environments
}

\author{
T. Singh ${ }^{1 *}$, J. S. Dureja ${ }^{1}$, M. Dogra ${ }^{2}$ and M. S. Bhatti ${ }^{3}$ \\ ${ }^{1}$ Department of Mechanical Engineering, Punjabi University Patiala, India \\ ${ }^{2}$ Department of Mechanical Engineering, S S Giri, Panjab University Regional \\ Center, Hoshiarpur, Punjab, India \\ ${ }^{3}$ Department of Botanical and Environmental Sciences, Guru Nanak Dev \\ University, Amritsar, Punjab, India \\ *Email: tp_tiet@yahoo.co.in \\ Phone: +91-9501460077, Fax: +91-175-3046333
}

\begin{abstract}
Environment friendly machining calls for minimizing the use of cutting fluids to reduce their negative impact on environment and operator health. Present experimental work is aimed to investigate machining performance of AISI 304 austenitic stainless steel with PVD coated carbide tool under different turning environments viz. dry, flooded and nanofluid minimum quantity lubrication (NF-MQL). Optimum turning parameters obtained through desirability function optimisation are found as: cutting speed of 160.67 $\mathrm{m} / \mathrm{min}$, feed of $0.06 \mathrm{~mm} / \mathrm{rev}$ and depth of cut of $0.25 \mathrm{~mm}$ with predicted tool flank wear of $100.001 \mu \mathrm{m}$ and surface roughness of $0.509 \mu \mathrm{m}$ at 0.808 desirability level. Confirmation tests show $3.22 \%$ and $3.41 \%$ error between predicted and experimental values of $\mathrm{V}_{\mathrm{b}}$ and $\mathrm{Ra}$, respectively. Present study has established the superiority of NFMQL machining over dry and flooded machining. The most salient achievement of this investigation is the reduction of tool flank wear by $32.26 \%$ under NF-MQL machining compared to dry machining and $9.68 \%$ compared to flooded machining conditions. Similarly, NF-MQL exhibits improvement in surface finish by $34.72 \%$ and $7.59 \%$ over dry and flooded coolant environments respectively, thus providing a strong basis to replace flooded coolant machining for sustainable future.
\end{abstract}

Keywords: Turning; flank wear; nanofluid minimum quantity lubrication; MQL; surface roughness; dry machining.

\section{NOMENCLATURE}

$\begin{array}{ll}\text { MQL } & \text { minimum quantity lubrication } \\ \text { MQCL } & \text { minimum quantity cooling lubrication } \\ \text { NF-MQL } & \text { nanofluid minimum quantity lubrication } \\ \text { MWCNT } & \text { multiwall carbon nanotubes } \\ \text { PVD } & \text { physical vapour deposition } \\ \text { AISI } & \text { American Iron and Steel Institute } \\ \text { CCRD } & \text { central composite rotatable design } \\ \text { RSM } & \text { response surface methodology } \\ \text { ANOVA } & \text { analysis of variance } \\ V_{b} & \text { tool flank wear }(\mu \mathrm{m}) \\ \text { Ra } & \text { surface roughness }(\mu \mathrm{m})\end{array}$




$\begin{array}{ll}\text { SEM } & \text { scanning electron microscope } \\ \text { EDAX } & \text { energy dispersive analysis through X-ray } \\ \mathrm{V}_{\mathrm{c}} & \text { cutting speed }(\mathrm{m} / \mathrm{min}) \\ \mathrm{f} & \text { feed }(\mathrm{mm} / \mathrm{rev}) \\ \mathrm{d} & \text { depth of cut }(\mathrm{mm}) \\ \text { BUE } & \text { built-up edge } \\ \text { BUL } & \text { built-up layer }\end{array}$

\section{INTRODUCTION}

Austenitic stainless steel, AISI 304 is one of the highly used steel grades particularly in food processing and chemical equipment, pressure vessels, automobile and aerospace components, paper industry etc. due to its high strength and excellent corrosion resistance. It also has many other favourable properties which include fatigue resistance, excellent weldability and oxidation resistance [1,2]. However, machining of AISI 304 stainless steel is commonly followed by some difficulties such as rapid work hardening, built-up edge formation, lesser tool life and high cutting zone temperature [3, 4]. Because of high strength and fracture strain of such alloys, high cutting energy is required when compared with low-strength alloys like plain carbon steel [5]. Also, poor heat conductivity of AISI 304 results in high cutting zone temperature during machining which leads to faster tool wear and low surface quality [6]. All of this place AISI 304 stainless steel in the class of difficult-to-cut materials. Cutting fluids play a major role in addressing machining problems in such situations [7]. Functions such as enhancing cutting tool life, reducing friction, heat dissipation and improving machined surface integrity are obtained by using cutting fluids due to their lubricant, cooling and chips evacuation properties [8,9].

On the other hand, harmful chemical elements of cutting fluids cause environment pollution and user health hazards [10-13]. Furthermore, applying cost of cutting fluids is $17 \%-20 \%$ of production cost compared to $8 \%$ tooling cost [14-16]. Several alternatives like dry machining, NDM (near dry machining) / MQL (minimum quantity lubrication) have been explored to reduce or even eliminate cutting fluids in machining applications to attain environment conscious and economical machining operations [17-19].

Many researchers witnessed improved machining performance under MQL over dry cutting and restricted environmental wet (flooded) cooling conditions. In MQL, highvelocity jet comprises a small quantity of lubricant/coolant $(10-100 \mathrm{ml} / \mathrm{h}$.) is sprayed between tool-chip interface with compressed air [20, 21]. Rahim et al. [22] investigated the reduction of cutting region temperature and cutting force by $30 \%$ and $28 \%$, respectively under MQL turning of AISI 1045 steel compared to dry machining. Yazid et al. [14] examined better-machined surface integrity of Inconel 718 with MQL machining. Accurate and closer penetration of lubricant into the cutting zone was observed under MQL conditions, resulting in lesser temperature and work hardening, consequently producing smoother surface texture compared to dry conditions. Gupta and Sood [23] experienced a decrease in surface roughness, cutting force, tool wear by $8.33 \%, 4.25 \%$, $8 \%$ and $7.79 \%, 4.08 \%, 10.03 \%$ under MQL machining of titanium (grade 2) and Inconel800 alloys, respectively compared to flood coolant conditions. Pervaiz et al. [24] claimed that turning of Ti6Al4V titanium alloy using minimum quantity cooling lubrication (MQCL) method can successfully replace conventional cooling conditions under machining parameters used in the experimentation.

Maruda et al. [25] investigated the effect of extreme pressure (EP) and anti-wear (AW) additives on surface integrity and tool wear while turning of AISI 1045 steel alloy 
under MQCL conditions. It was found that addition of phosphate ester-based additives in the base medium for MQCL resulted in enhanced lubricating action in the cutting zone due to the formation of tribo-film on the tool-chip interface. Results revealed MQCL with EP/AW additives lead to decrease in mean arithmetic surface height: Sa value by $8 \%$ (at feed rate $=0.3 \mathrm{~mm} / \mathrm{rev}$.) to $38 \%$ (at feed rate $=0.1 \mathrm{~mm} / \mathrm{rev}$.) compared to dry cutting environment. Also, the study claimed a reduction in tool flank wear under MQCL + EP/AW method by $8 \%$ and 23\% compared to MQCL and dry machining conditions, respectively. Similarly, another study conducted by Maruda et al. [26] experienced MQCL method produces favourable chip form (short spiral or quite loose) during turning of 316L austenitic stainless steel; such chips are easy to remove from the cutting zone, thereby results in improved machined surface quality. Park et al. [27] witnessed that MQL and cryogenic machining as a sustainable solution for eco-friendly face milling of titanium alloy (Ti-6Al-4V) due to lesser energy consumption, cutting forces and tool wear compared to dry and flood coolant environments. Pusavec et al. [28] experienced cryogenic machining coupled with MQL results in minimum surface roughness compared to dry, pure MQL, and cryogenic machining conditions while turning of Inconel 718. Likewise, superior machining performance in MQL turning of AISI 4340 hardenable steel and Inconel 718 over dry and wet machining has also been reported by Varadarajan et al. [29] and Thakur et al. [18], respectively.

Recently, nanoparticles and vegetable oils based cutting fluids have been incorporated with MQL technology [30]. Raju et al. [31] observed a reduction of tool wear by $30 \%$ and enhancement of surface finish by $9-22 \%$ using multiwall carbon nanotubes (MWCNT) based nanofluid while turning of EN 31 material compared to straight cutting fluid. These improvements are attributed to better lubrication properties and high heat conductivity of nanofluid leads to reduced friction and temperature at the tool-chip interface. Minh et al. [32] investigated nearly 35\% reduction in value of surface roughness under $\mathrm{Al}_{2} \mathrm{O}_{3}$ nanofluid MQL machining of $60 \mathrm{Si}_{2} \mathrm{Mn}$ steel because of superior tribological and cooling action of nanoparticles in the cutting zone. Sahu et al. [33] examined the performance of MWCNT nanofluid during turning of Ti-6Al-4V grade 5 titanium alloy. It was concluded that nanofluid results in $13 \%$ lesser tool wear and about $6.1 \%$ lower surface roughness compared to conventional coolant at cutting velocity of 90 $\mathrm{m} / \mathrm{min}$. Furthermore, improvement in tool life reaches up to $34 \%$ with nanofluid at a higher cutting rate of $150 \mathrm{~m} / \mathrm{min}$. Patole and Kulkarni [34] reported the best surface integrity of AISI 4340 steel under MQL turning with MWCNT nanoparticles compared to flooded cooling conditions. Similarly, Hegab et al. [35] witnessed MQL using MWCNT nanofluid presents enhanced results regarding power consumption and tool wear compared to pure MQL without nanoparticles.

Other studies [36-38] also claimed superior machining performance with nanofluid MQL during grinding of hardened AISI 52100 steel, milling of AISI 420 martensitic stainless steel and drilling of aluminium 6061 with $\mathrm{Al}_{2} \mathrm{O}_{3}, \mathrm{MoS}_{2}$ and diamond nanoparticles, respectively. However, limited research work has been reported on the application of ecological vegetable oils based nano cutting fluids under MQL machining. Krishna et al. [39] observed better performance in steel turning using nano boric acid particles reinforced in coconut oil based cutting fluid compared to SAE-40 base oil lubricant used earlier. Khan and Maity [40] investigated the superior surface quality of pure titanium (CP-Ti grade 2) under vegetable oil based MQL compared to other machining environments. Sharma et al. [41] observed improvement in cutting force, surface roughness and tool wear by $35.38 \%, 11.64 \%$ and $35.85 \%$, respectively in MQL turning of AISI 1040 steel with vegetable oil based nano cutting fluid using $\mathrm{TiO}_{2}$ 
nanoparticles over conventional machining conditions. Similarly, enhanced metal cutting performance under MQL with vegetable oils as cutting fluids has also been reported by Sharma and Sidhu [42], Khan et al. [43] and Lawal et al. [44] while turning of steel alloys viz. AISI D2, AISI 9310, and AISI 4340, respectively.

Few studies evaluate tool coating material performance under dry machining of hard-to-machine alloys. Devillez et al. [45] and Noordin et al. [46] investigated CVD coated carbide: $\mathrm{TiCN}-\mathrm{Al}_{2} \mathrm{O}_{3}$ - TiN as best suited tool coating material for the dry turning of Inconel 718 and hardened stainless steel. Whereas, Ginting and Nouari [47] revealed uncoated carbide cutting tool gives better surface quality during finish operations of Ti6242S titanium alloy in a dry machining environment. Nouari et al. [48] examined tungsten coated carbide drill results in enhanced machining performance of AA2024 aluminium alloy under dry drilling conditions. Alok and Das [49] claimed newly developed coating material: $\mathrm{HSN}^{2}$ (TiAlxN super nitride) on carbide tool can be successfully used for machining EN-31 (AISI 52100 hardened steel: 55 HRC). Fukui et al. [50] experienced DLC coated (diamond-like carbon) tool provides improved surface quality and tool performance in dry milling of aluminium alloys: $\mathrm{AlMg} 2.5$ and $\mathrm{AlCu} 4.5 \mathrm{Si} 12$ compared to the uncoated cutting tool.

The improvement of tool performance and machined surface integrity mainly depends upon machining parameters like cutting speed, feed, depth of cut etc. Therefore, the optimization of these parameters is important to minimise tool wear and surface roughness. Mia and Dhar [51] optimised machining parameters in hard turning of AISI 1060 steel under high-pressure coolant (HPC) conditions using the Taguchi method. Results for workpiece hardness of $40 \mathrm{HRC}$ showed that the optimum level of parameters to minimise surface roughness was at cutting speed of $161 \mathrm{~m} / \mathrm{min}$, feed rate of 0.12 $\mathrm{mm} / \mathrm{rev}$, whereas optimum cutting temperature was attained at $81 \mathrm{~m} / \mathrm{min}$ cutting speed for same feed rate and workpiece hardness. Besides, HPC conditions resulted in lesser surface roughness, cutting temperature and tool wear by $12.9 \%, 10.8 \%$ and $29.4 \%$, respectively compared to dry machining conditions. Makadia and Nanavati [52] modelled surface roughness using RSM (response surface methodology) while machining of AISI 410 steel alloy and observed lowest feed rate results in optimum machined surface finish. Similarly, Sarikaya and Gullu [53] generated a mathematical model for surface roughness through RSM during machining of AISI 1050 steel under MQL conditions. Results revealed feed rate and cooling conditions as significant model terms affecting surface quality.

In another study conducted by Mia [54] employs RSM based desirability multiresponse optimisation module to minimise specific cutting energy and surface roughness in end milling of hardened AISI 4140 steel under MQL conditions. Results revealed optimize machining parameters as: cutting speed $=32 \mathrm{~m} / \mathrm{min}$., feed rate $=46 \mathrm{~mm} / \mathrm{min}$ and MQL flow rate $=150 \mathrm{ml} / \mathrm{h}$ to attain enhanced milling performance. Similarly, Alok and das [55] utilised RSM multi-response desirability optimisation function for simultaneous minimisation of cutting forces, surface roughness and tool wear in dry hard turning of AISI 52100 steel alloy. Optimum process parameters was at cutting speed of $194.77 \mathrm{~m} / \mathrm{min}$, feed rate of $0.08 \mathrm{~mm} / \mathrm{rev}$ and depth of cut of $0.06 \mathrm{~mm}$ with desirability level of 0.823. Rabiei et al. [56] developed surface roughness model based on RSM in grinding of soft steels (CK45 and S305) under MQL technique. By utilising genetic algorithm optimization approach, the optimum grinding parameters was at depth of cut of $15 \mu \mathrm{m}$, grinding wheel speed of $20.9 \mathrm{~m} / \mathrm{s}$ and feed rate of $37.5 \mathrm{~mm} / \mathrm{s}$ with predicted surface roughness of $0.42 \mu \mathrm{m}$. 
From the literature review, it is revealed that MQL is used for all types of machining processes i.e. turning, milling, grinding and drilling. Most of the MQL machining research work has been conducted on Ni-Cr alloys like Inconel 800, Inconel 718, hardened steel alloys viz. AISI 52100, AISI 1050, AISI 1045, AISI 4340, AISI D2, AISI 9310, $6061 \mathrm{Al}$ alloy and titanium alloys etc. using a different combination of cutting parameters, MQL parameters and cooling strategies. Since MQL is a relatively new technique and the research has not been completely established. Consequently, there is a large scope of improvement and thus it is important to explore the application of this technique in machining processes. Few research studies have also been reported on the utilisation of nanofluids under MQL machining to enhance tool life and surface finish. However, no study is available on turning of AISI 304 austenitic stainless steel using soybean oil reinforced with MWCNT based cutting fluid under nanofluid minimum quantity lubrication (NF-MQL). Therefore, the main objective of the present experimental study was to investigate machining performance of AISI 304 stainless steel regarding tool flank wear and surface roughness with PVD coated carbide tool under different environments viz. dry, flooded and NF-MQL.

\section{MATERIALS AND METHOD}

\section{Workpiece}

The workpiece material selected for this study was AISI 304 austenitic stainless steel bar (Ø70 mm x $370 \mathrm{~mm}$ ). AISI 304 is a widely used grade in manufacturing industries and is considered difficult-to-cut material due to rapid work hardening, built-up edge formation, high strength and poor heat conductivity [1-4]. Typical mechanical properties of AISI 304 stainless steel at nominal room-temperature are tensile strength of $577 \mathrm{MPa}$, yield strength of $267 \mathrm{MPa}$, Young modulus of $193 \times 10^{3} \mathrm{MPa}$, density of $8.0 \mathrm{~g} / \mathrm{cm}^{3}$, melting range of $1400-1455^{\circ} \mathrm{C}$, thermal conductivity of $13.8 \mathrm{~W} / \mathrm{m}-\mathrm{K}$ and; hardness of $182 \mathrm{HB}$. Alloying element composition of AISI 304 stainless steel is $8.41 \% \mathrm{Ni}, 18.58 \% \mathrm{Cr}, 1.82 \%$ Mn, $0.033 \%$ P, $0.82 \% \mathrm{Si}, 0.022 \% \mathrm{~S}, 0.055 \% \mathrm{C}$.

\section{Cutting Tool}

Cutting tool material selected for the turning tests was PVD coated carbide: GradeVP10RT, coating material: (Al, Ti) N imported from Mitsubishi Materials Corporation, Japan having specifications shown in Table 1. Coated grade VP10RT provides a good balance of wear and fracture resistance [57]. Widia tool holder: MTJNL2020 M16 and insert that provide $93^{\circ}$ approach angle, $6^{\circ}$ clearance angle, $1.2 \mathrm{~mm}$ nose radius and $-6^{\circ}$ rake angle after clamped.

\section{Nanofluid}

In this study, soybean oil was used as base fluid due to its significant properties such as biodegradability, no worker health hazard issues, environmentally friendly and high viscosity: $48.0 \mathrm{cP}[44,58,59]$. To prepare nanofluid samples, different weight $\%$ of hydroxyl functionalized multiwall carbon nanotubes (MWCNT: Average L $=1-5 \mu \mathrm{m}$ and $\varnothing=10-15 \mathrm{~nm}$ ) were mixed in soybean oil using ultrasonic vibrator: $40 \mathrm{kHz}, 100 \mathrm{~W}$ for 1 hour and magnetic stirrer for about 30 minutes [60]. MWCNT: allotrope of carbon consisting multiple cylindrical graphene layers, were selected because of their higher heat 
conductivity: $~ 3000 \mathrm{~W} / \mathrm{m}-\mathrm{k}$ compared to $\mathrm{MoS}_{2}, \mathrm{Al}_{2} \mathrm{O}_{3}, \mathrm{TiO}_{2}$ and other nanoparticles [33]. In addition, hydroxyl functionalized MWCNT gives excellent dispersion and compatibility with solvents and polymers [61]. Furthermore, MWCNT provides high thermal and chemical stability resulting from their multiwall interactions compared to single wall carbon nanotubes (SWCNT) [62]. Various studies [31, 33-35] also claimed enhanced machining performance with MWCNT nanofluid compared to traditional cutting fluids. The base fluid and prepared nanofluid sample are shown in Figure 1(a) and (b), respectively. Performance of different nanofluid samples was evaluated on basis of $\mathrm{V}_{\mathrm{b}}$ under MQL conditions as depicted in Figure 2. Nanofluid prepared with $1 \%$ MWCNT concentration confirms minimum value of $\mathrm{V}_{\mathrm{b}}$ compared to other nanofluid samples and pure soybean oil [36, 37, 41].

Table 1. Cutting insert specifications.

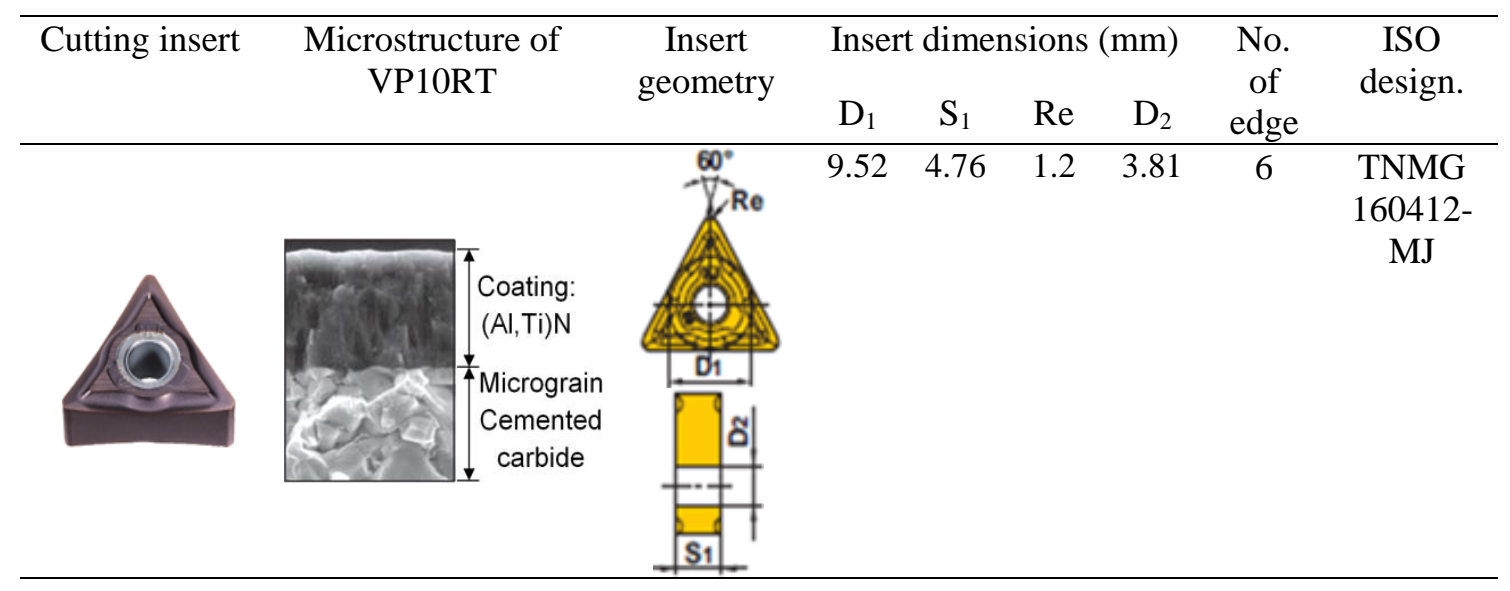

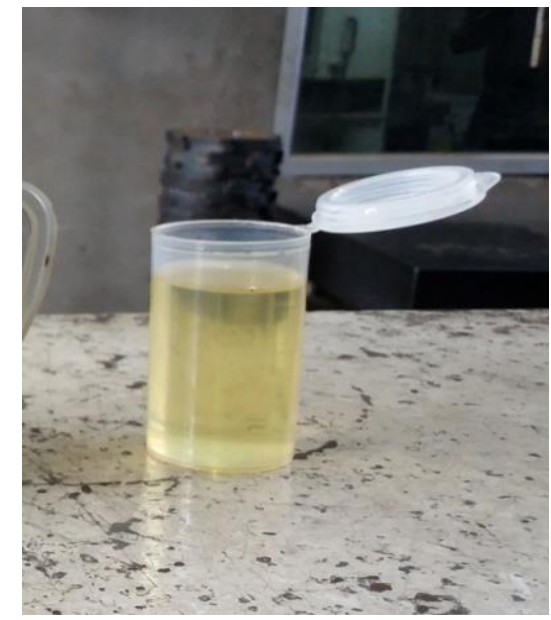

(a)

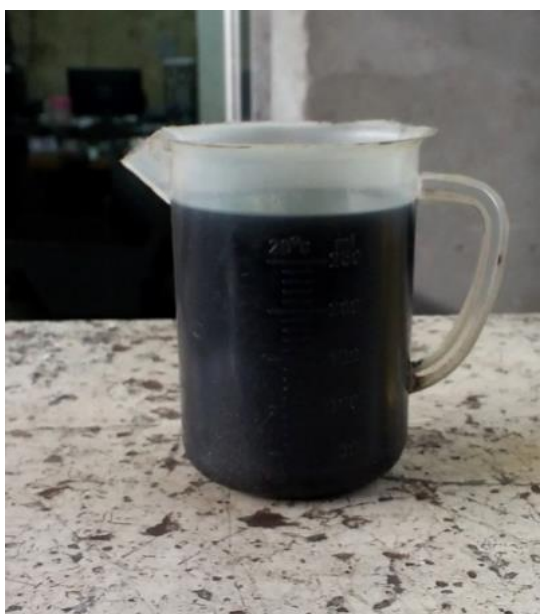

(b)

Figure 1. (a) Pure soybean oil as base fluid/lubricant: (b) Soybean oil reinforced with MWCNTs nanofluid 


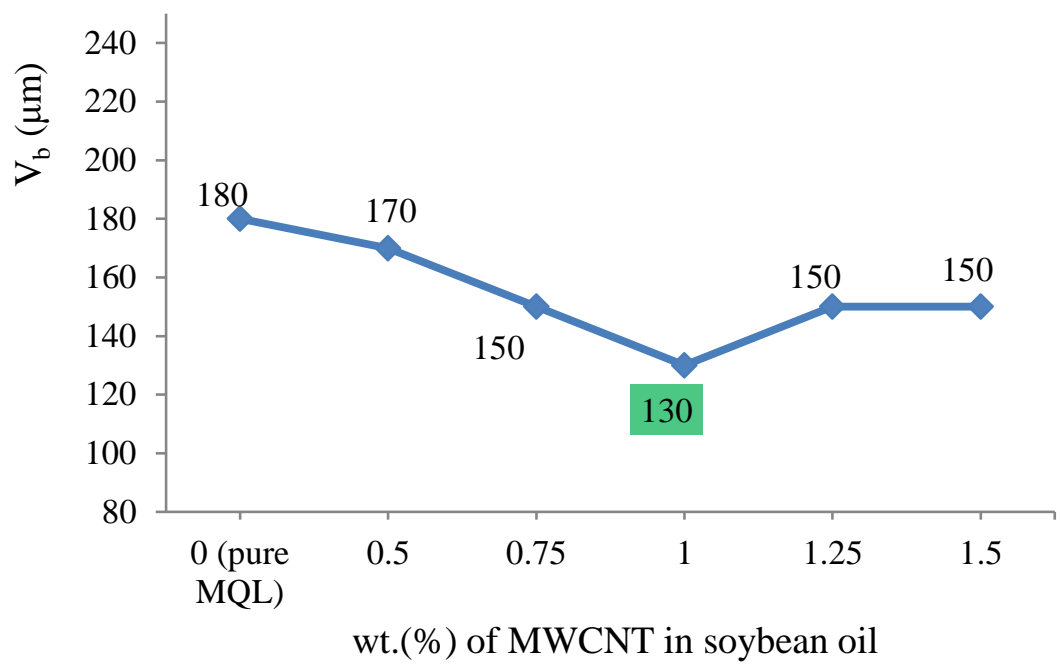

Figure 2. Performance of nanofluid samples at $V_{c}=215 \mathrm{~m} / \mathrm{min}$., $\mathrm{f}=0.1 \mathrm{~mm} / \mathrm{rev}$ and $\mathrm{d}=$ $0.25 \mathrm{~mm}$.

\section{Nanofluid MQL (NF-MQL) Supply Unit}

In nanofluid MQL (NF-MQL) machining system, the nanofluid jet is injected in the cutting zone with high velocity through NF-MQL nozzle using compressed air pressure. NF-MQL supply unit (Model: MC3100) used in the current study was imported from Noga Engineering and Technology Ltd., Israel. Figure 3(a) shows working principle of NF-MQL supply system based on venturi approach to spray high-velocity jet/mist of air and nanofluid mixture at the work-chip-tool interface. One pipeline of the NF-MQL system was connected to the available compressed air supply (at 6 bar) and the other NFMQL pipeline was dipped in the nanofluid container. When the compressed air enters in venturi section, it creates a vacuum around the NF-MQL nozzle which causes nanofluid to rise and reaches in the mixing zone of the nozzle through the nanofluid supply line. The air and nanofluid mixture exit from the nozzle as high-velocity jet. The flow rate of NF-MQL jet can be adjusted with the help of a knob and nozzle nut. The nozzle is placed nearly $20 \mathrm{~mm}$ above from the edge of cutting insert by a magnetic base and flexible hose of NF-MQL unit as shown in Figure 3(b). $75 \mathrm{ml} / \mathrm{h}$ flow rate of NF-MQL jet was used during turning tests, primarily to target flank and rake faces of the cutting tool to enhance machining performance.

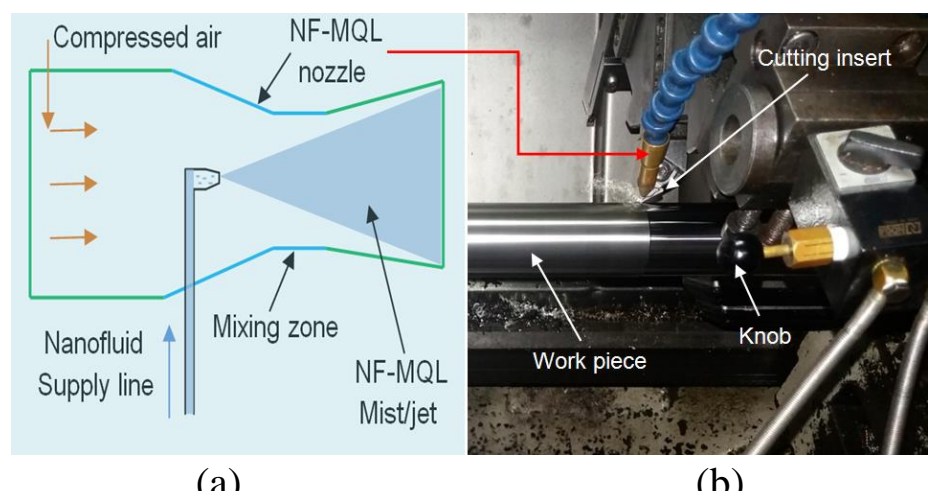

(a)

(b)

Figure 3. NF-MQL supply unit 


\section{Experimental Design and Procedure}

Turning tests were conducted on high-rigidity CNC lathe machine; Model: stallion-100 HS; make: HMT having servo tool turret with 8 Stations. Three machining parameter $(\mathrm{p}=3)$ : cutting speed $\left(\mathrm{V}_{\mathrm{c}}\right)$, feed (f) and depth of cut $(\mathrm{d})$ were identified as input turning parameters and their range was finalised based on tool manufacturer recommendations, literature review and results of pilot experiments [4, 63-65]. Tool flank wear ( $\mathrm{Vb})$ and surface roughness $(\mathrm{Ra})$ were the machining performance indicators or response factors. The desired objective was to achieve a minimum value of $\mathrm{Vb}$ and $\mathrm{Ra}$.

In the present work, a sequential design methodology was followed. Design expert 7.0 version software was used to obtain a central composite rotatable design (CCRD) plan for the first design stage based on response surface methodology (RSM). CCRD includes eight corners or factorial points $\left( \pm 1\right.$ level; $\left.2^{\mathrm{p}}=8\right)$, center points $(0$ level $)$ and user-defined axial or star points $( \pm \alpha$ level; $2 \mathrm{p}=6$ with $\alpha=1.682)$. To ascertain repeatability of the machine used, experiments were repeated five times at center level. Total 19 tests were carried out under NF-MQL conditions at five levels $( \pm \alpha, \pm 1$ and 0 ; Table 2$)$ as per obtained CCRD design plan and result measured for response factors: $\mathrm{Vb}$ and $\mathrm{Ra}$ were examined statistically by ANOVA analysis.

Table 2. CCRD design plan with results: Actual value (coded value).

\begin{tabular}{lccccc}
\hline Test No. & $\mathrm{V}_{\mathrm{c}}(\mathrm{m} / \mathrm{min})$ & $\mathrm{f}(\mathrm{mm} / \mathrm{rev})$ & $\mathrm{d}(\mathrm{mm})$ & $\mathrm{V}_{\mathrm{b}}(\mu \mathrm{m})$ & $\mathrm{Ra}(\mu \mathrm{m})$ \\
\hline 1 & $155(-1)$ & $0.06(-1)$ & $0.35(+1)$ & 110 & 0.69 \\
2 & $185(0)$ & $0.1(0)$ & $0.3(0)$ & 160 & 0.48 \\
3 & $185(0)$ & $0.1(0)$ & $0.3(0)$ & 140 & 0.45 \\
4 & $215(+1)$ & $0.06(-1)$ & $0.35(+1)$ & 200 & 0.51 \\
5 & $215(+1)$ & $0.14(+1)$ & $0.25(-1)$ & 120 & 0.53 \\
6 & $185(0)$ & $0.1(0)$ & $0.3(0)$ & 130 & 0.47 \\
7 & $155(-1)$ & $0.06(-1)$ & $0.25(-1)$ & 100 & 0.58 \\
8 & $215(+1)$ & $0.14(+1)$ & $0.35(+1)$ & 130 & 0.65 \\
9 & $155(-1)$ & $0.14(+1)$ & $0.35(+1)$ & 170 & 0.76 \\
10 & $215(+1)$ & $0.06(-1)$ & $0.25(-1)$ & 150 & 0.48 \\
11 & $155(-1)$ & $0.14(+1)$ & $0.25(-1)$ & 170 & 0.65 \\
12 & $134.55(-\alpha)$ & $0.1(0)$ & $0.3(0)$ & 110 & 0.67 \\
13 & $235.45(+\alpha)$ & $0.1(0)$ & $0.3(0)$ & 190 & 0.36 \\
14 & $185(0)$ & $0.17(+\alpha)$ & $0.3(0)$ & 140 & 0.79 \\
15 & $185(0)$ & $0.1(0)$ & $0.38(+\alpha)$ & 150 & 0.48 \\
16 & $185(0)$ & $0.1(0)$ & $0.22(-\alpha)$ & 140 & 0.38 \\
17 & $185(0)$ & $0.1(0)$ & $0.3(0)$ & 130 & 0.42 \\
18 & $185(0)$ & $0.03(-\alpha)$ & $0.3(0)$ & 120 & 0.45 \\
19 & $185(0)$ & $0.1(0)$ & $0.3(0)$ & 120 & 0.49 \\
\hline
\end{tabular}

Each experiment was performed by using a fresh cutting edge of the tool. The helical / sliding cutting length: $\mathrm{Lc}=1350 \mathrm{~m}$ was kept same for all experimental runs as a reference factor to evaluate the performance of PVD coated carbide tool, as this lies in the steady-state wear region (Zone-II) during the life cycle of the cutting tool; observed while conducted preliminary experiments. As per ISO 3685: 1993 standards, the value of tool flank wear in the study represents $\mathrm{V}_{\mathrm{b}}$ (Zone-B); measured with the help of Metzer toolmaker's microscope (magnification options: X30 to X150; resolution: $10 \mu \mathrm{m}$ ). The 
toolmaker's microscope lens has marked cross-hair, which act as reference lines. The cutting insert wear profile seen through the magnifying lens was set to coincide with horizontal reference line to note down the initial micrometre reading. Then, the table with the tool was moved such that cross-hair line passes through average flank wear profile; here final micrometre reading was taken and the difference of two micrometre readings gave a value of average $\mathrm{V}_{\mathrm{b}}$. Surface roughness was evaluated during turning tests with Mitutoyo surftest analyser (Model: SJ-201, Japan) having cut-off length $=0.8 \mathrm{~mm}$. SEM/EDAX images were captured with JEOL scanning electron microscope (Model: JSM 6510-LV, Japan). Surface roughness was recorded at three different positions over the machined workpiece surface, and their average value is shown in the results.

\section{RESULTS AND DISCUSSION}

\section{Analysis of Variance (ANOVA)}

Response factors $\left(\mathrm{V}_{\mathrm{b}}\right.$ and $\mathrm{Ra}$ ) models were generated and evaluated for input turning parameters $\left(\mathrm{V}_{c}, \mathrm{f}\right.$ and $\mathrm{d}$ ) through $\mathrm{RSM}$ approach. Two-factor interaction (2FI) model was observed as best fit model for response $\mathrm{V}_{\mathrm{b}}$, whereas quadratic model was found as best fit model for second response Ra. The statistical significance of these fitted models along with input machining parameters was investigated by using ANOVA. Table 3 and 4 shows the ANOVA test result for $\mathrm{V}_{\mathrm{b}}$ and $\mathrm{Ra}$. The $\mathrm{F}$-value of 20.77 for $\mathrm{V}_{\mathrm{b}}-2 \mathrm{FI}$ model and 22.45 for Ra-quadratic model is considerable large and thus reflecting good significance of both fitted models. The significance of input parameters and their interaction with each other can be examined from their corresponding p-value (Prob $>F$ ). The contribution of parameters is significant if $\mathrm{p}$-value is $<0.05$ (Prob $>\mathrm{F}$ ). It was found from the Table 3 and 4 that $V_{c}$ and cutting speed-feed $\left(V_{c}-f\right)$ interaction are the statistically significant parameters for $\mathrm{V}_{\mathrm{b}}$, however all input parameters: $\mathrm{V}_{\mathrm{c}}, \mathrm{f}$ and $\mathrm{d}$ are significant model terms for Ra.

Cutting speed with feed $\left(\mathrm{V}_{\mathrm{c}}-\mathrm{f}\right)$ interaction has maximum influence on tool flank wear with the percentage contribution of $61.2 \%$, followed by $\mathrm{V}_{\mathrm{c}}$ at $26.9 \%$ and feed at $0.1 \%$. Whereas, surface roughness is the most sensitive to $\mathrm{V}_{\mathrm{c}}$ with percentage contribution of $28.6 \%$, followed by feed at $21.4 \%$ and depth of cut of $7.1 \%$. The lack of fit for both models is non-significant as desired. $\mathrm{V}_{\mathrm{b}}$ and $\mathrm{Ra}$ model statistics reveal that coefficient of variation (C.V.) value is less than $10 \%$ and $\mathrm{R}^{2}$ (coefficients of correlation) value approaches to 1 , thereby reflects good sign about the correctness and reliability of the experiments performed. Likewise, adjusted $R^{2}$ and predicted $R^{2}$ values for $V_{b}$ and $R a$ models are noticed near to each other which further confirms the fitness of developed models. Adequate precision value $>14$, indicates well suitability of models for future predictions. Consequently, empirical model equations obtained through multiple regression analysis as presented in Table 5 can be applied for prediction of tool wear and surface roughness in terms of input turning parameters. The predicted model values given by these regression equations are compared with the experimentally observed values of $\mathrm{V}_{\mathrm{b}}$ and $\mathrm{Ra}$ in order to check the accuracy of developed models. Figure 4 shows predicted and experimental measured values of $\mathrm{V}_{\mathrm{b}}$ and $\mathrm{Ra}$ are in good agreement with each other. 
Table 3. ANOVA results for tool flank wear.

\begin{tabular}{|c|c|c|c|c|c|c|c|}
\hline Source & $\begin{array}{l}\text { Sum of } \\
\text { Squares }\end{array}$ & $\mathrm{DF}^{*}$ & $\begin{array}{l}\text { Mean } \\
\text { Square }\end{array}$ & F Value & $\begin{array}{l}\text { p-value } \\
\text { Prob > F }\end{array}$ & Remarks & $\begin{array}{l}\text { PC } \\
(\%)\end{array}$ \\
\hline Model & 10888.69 & 3 & 3629.56 & 20.77 & $<0.0001$ & significant & \\
\hline $\mathrm{V}_{\mathrm{c}}$ & 3582.16 & 1 & 3582.16 & 20.50 & 0.0006 & significant & 26.9 \\
\hline $\mathrm{f}$ & 14.08 & 1 & 14.08 & 0.08 & 0.78 & $\begin{array}{c}\text { not } \\
\text { significant }\end{array}$ & 0.1 \\
\hline $\begin{array}{l}\left(V_{c}-f\right) \\
\text { interaction }\end{array}$ & 8134.87 & 1 & 8134.87 & 46.56 & $<0.0001$ & significant & 61.2 \\
\hline Residual & 2271.31 & 13 & 174.72 & & & & 11.8 \\
\hline Lack of Fit & 1754.65 & 10 & 175.46 & 1.02 & 0.56 & $\begin{array}{c}\text { not } \\
\text { significant }\end{array}$ & \\
\hline Pure Error & 516.67 & 3 & 172.22 & & & & \\
\hline Cor. Total & 13294.44 & 17 & & & & & \\
\hline \multicolumn{8}{|c|}{ Model Statistics } \\
\hline \multirow{2}{*}{\multicolumn{2}{|c|}{$\begin{array}{l}\text { Std. Dev. } \\
\text { Mean }\end{array}$}} & \multicolumn{2}{|r|}{13.22} & \multicolumn{2}{|c|}{$\mathrm{R}^{2}$} & \multicolumn{2}{|c|}{0.83} \\
\hline & & \multicolumn{2}{|r|}{140.56} & \multicolumn{2}{|c|}{ Adjusted $\mathrm{R}^{2}$} & \multicolumn{2}{|c|}{0.79} \\
\hline C.V. \% & & \multicolumn{2}{|r|}{9.40} & \multicolumn{2}{|c|}{ Predicted $\mathrm{R}^{2}$} & \multicolumn{2}{|c|}{0.67} \\
\hline Press & & \multicolumn{2}{|r|}{4301.20} & \multicolumn{2}{|c|}{ Adequate Precision } & \multicolumn{2}{|c|}{14.92} \\
\hline
\end{tabular}

*Degree of freedom.

Table 4. ANOVA results for surface roughness.

\begin{tabular}{|c|c|c|c|c|c|c|c|}
\hline Source & $\begin{array}{l}\text { Sum of } \\
\text { Squares }\end{array}$ & $\mathrm{DF}^{*}$ & $\begin{array}{c}\text { Mean } \\
\text { Square }\end{array}$ & $\begin{array}{c}\mathrm{F} \\
\text { Value }\end{array}$ & $\begin{array}{l}\mathrm{p} \text {-value } \\
\text { Prob > F }\end{array}$ & Remarks & $\begin{array}{l}\mathrm{PC} \\
(\%)\end{array}$ \\
\hline Model & 0.24 & 5 & 0.048 & 22.45 & $<0.0001$ & significant & \\
\hline $\mathrm{V}_{\mathrm{c}}$ & 0.08 & 1 & 0.078 & 36.46 & $<0.0001$ & significant & 28.6 \\
\hline $\mathrm{f}$ & 0.06 & 1 & 0.06 & 27.88 & 0.0002 & significant & 21.4 \\
\hline d-DOC & 0.02 & 1 & 0.021 & 9.93 & 0.008 & significant & 7.1 \\
\hline$\left(\mathrm{V}_{\mathrm{c}}\right)^{2}$ & 0.017 & 1 & 0.017 & 7.85 & 0.016 & significant & 6.5 \\
\hline$(f)^{2}$ & 0.072 & 1 & 0.072 & 33.65 & $<0.0001$ & significant & 25.9 \\
\hline Residual & 0.026 & 12 & 0.0021 & & & & 10.5 \\
\hline Lack of Fit & 0.023 & 9 & 0.0025 & 2.60 & 0.23 & $\begin{array}{c}\text { not } \\
\text { significant }\end{array}$ & \\
\hline Pure Error & 0.003 & 3 & 0.001 & & & & \\
\hline Cor. Total & 0.28 & 18 & & & & & \\
\hline \multicolumn{8}{|c|}{ Model Statistics } \\
\hline Std. Dev. & & & 0.05 & \multicolumn{2}{|l|}{$\mathrm{R}^{2}$} & \multicolumn{2}{|c|}{0.91} \\
\hline Mean & & & 0.54 & \multicolumn{2}{|c|}{ Adjusted $\mathrm{R}^{2}$} & \multicolumn{2}{|c|}{0.86} \\
\hline C.V. $\%$ & & & 8.53 & \multirow{2}{*}{\multicolumn{2}{|c|}{$\begin{array}{l}\text { Predicted } \mathrm{R}^{2} \\
\text { Adequate Precision }\end{array}$}} & \multicolumn{2}{|c|}{0.57} \\
\hline Press & & & 0.11 & & & \multicolumn{2}{|c|}{14.78} \\
\hline
\end{tabular}

*Degree of freedom.

Table 5. Empirical model equations for $\mathrm{V}_{\mathrm{b}}$ and $\mathrm{Ra}$.

\begin{tabular}{ll}
\hline Response factors & Empirical model equations \\
\hline $\mathrm{V}_{\mathrm{b}}$ & $-502.99+3.48 * \mathrm{~V}_{\mathrm{c}}+5403.22 * \mathrm{f}-29.06 * \mathrm{~V}_{\mathrm{c}} * \mathrm{f}$ \\
& \\
$\mathrm{Ra}$ & $+2.29-0.0167 * \mathrm{~V}_{\mathrm{c}}-7.32 * \mathrm{f}+0.79 * \mathrm{~d}+0.00004 * \mathrm{~V}_{\mathrm{c}}^{2}+$ \\
& $44.87 * \mathrm{f} 2$ \\
\hline
\end{tabular}




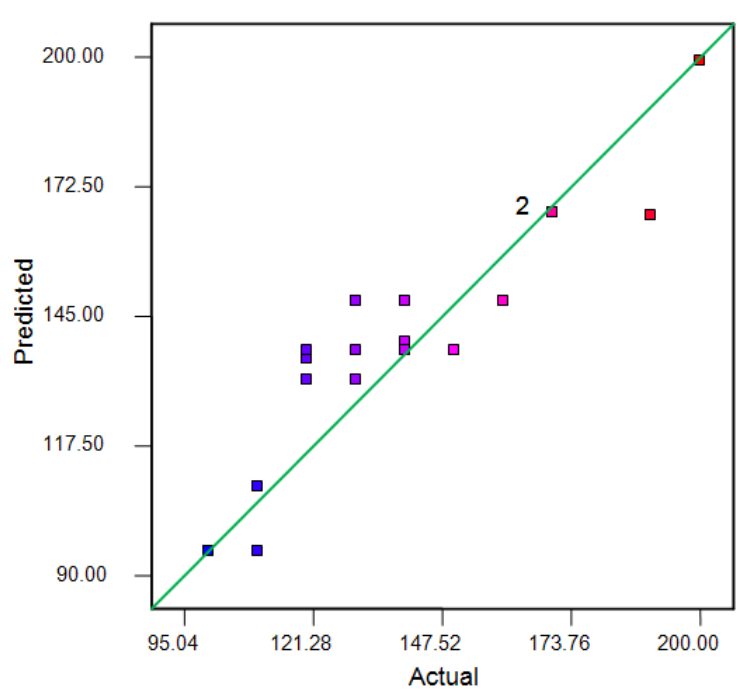

(a)

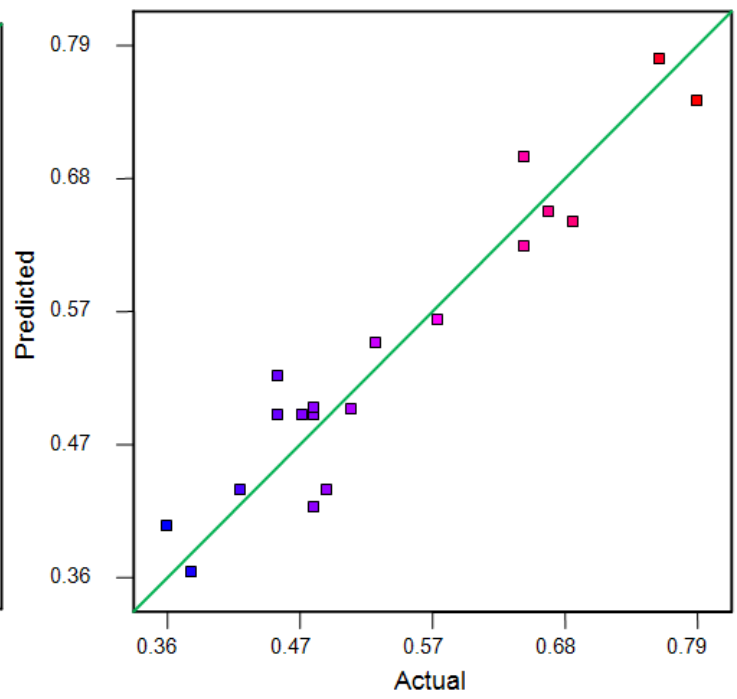

(b)

Figure 4. Comparison between predicted and actual values of (a) $V_{b}$ and; (b) Ra.

\section{Influence of Machining Parameters on Tool Wear and Surface Roughness}

Figure 5 illustrates the influence of turning parameters $\left(\mathrm{V}_{\mathrm{c}}, \mathrm{f}\right.$ and $\left.\mathrm{d}\right)$ on experimental observed values of tool flank wear $\left(\mathrm{V}_{\mathrm{b}}\right)$ under NF-MQL environment. Initially, tool wear increases at slow rate with change in cutting speed from $-\alpha$ to 0 : lowest to middle value $(134.55-185 \mathrm{~m} / \mathrm{min}$.) as observed in Figure 5(a). However, tool wear grows rapidly with further increase in cutting speed from $185-235.45 \mathrm{~m} / \mathrm{min}$. Turning conditions under upper level of cutting speed become more aggressive due to uneven tool-chip contact leading to high cutting and frictional forces, thereby accelerates tool wear rate [23]. The value of tool wear is minimal affected by change in feed levels from $0.03-0.17 \mathrm{~mm} / \mathrm{rev}$. as noticed in Figure 5(b). The effect of depth of cut on $\mathrm{V}_{\mathrm{b}}$ is shown in Figure 5(c).

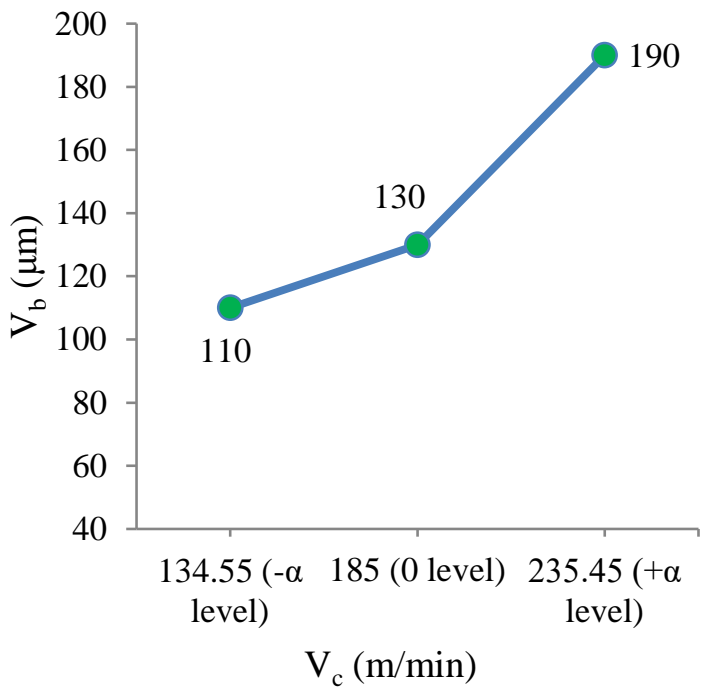

(a)

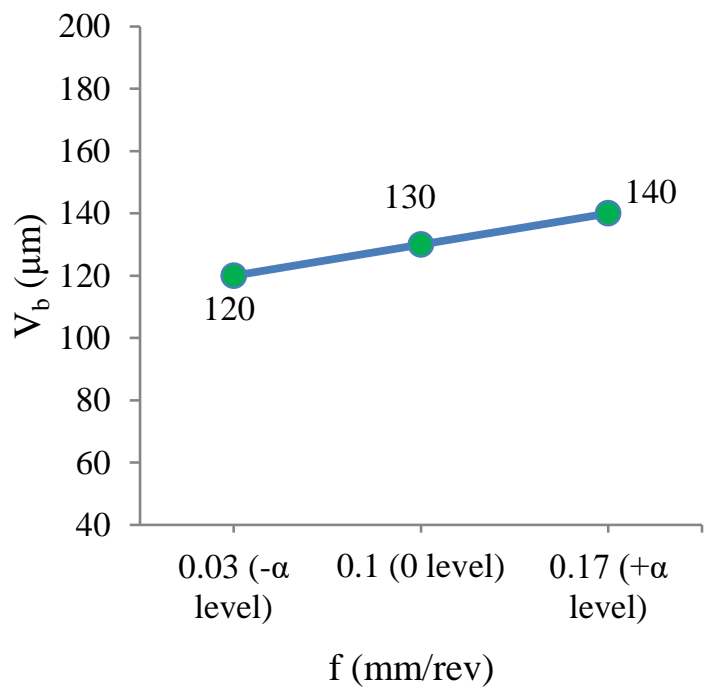

(b) 


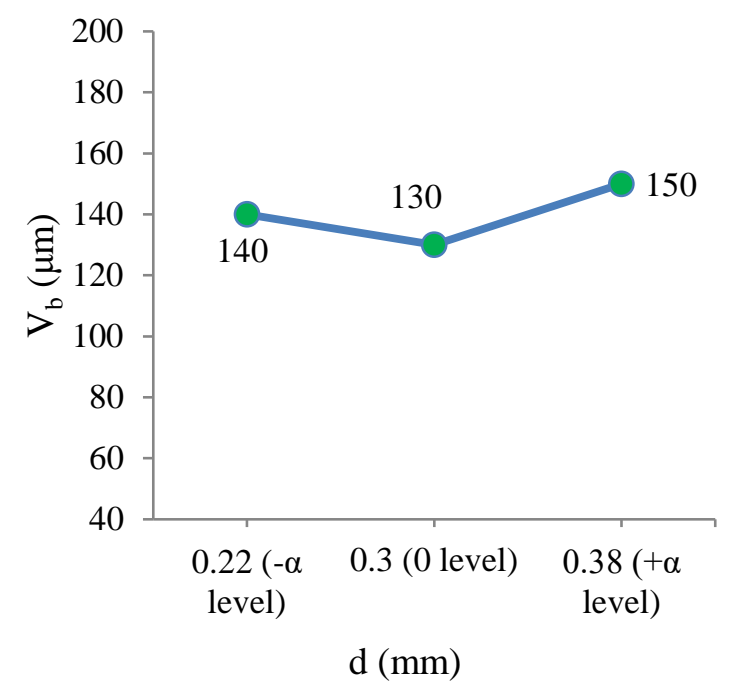

(c)

Figure 5. Effect of (a) cutting speed (at $0.1 \mathrm{~mm} / \mathrm{rev}$ feed, $0.3 \mathrm{~mm}$ depth of cut), (b) feed (at $185 \mathrm{~m} / \mathrm{min}$ cutting speed, $0.3 \mathrm{~mm}$ depth of cut) and; (c) depth of cut (at $185 \mathrm{~m} / \mathrm{min}$ cutting speed, $0.1 \mathrm{~mm} / \mathrm{rev}$ feed) on tool flank wear.

It was observed that changing depth of cut from $0.22-0.3 \mathrm{~mm}$, doesn't affect tool life significantly, however tool wear increases with further increase in depth of cut from $0.3-0.38 \mathrm{~mm}$. This is due to fact that, higher depth of cut needs more cutting energy and force to remove large amount of work piece material which causes more tool wear compared to lower level of depth of cut. Hegab et al. [35] and Krishna et al. [39] experienced similar behavior of tool wear variation with change in machining parameters during turning of Ti-6Al-4V and AISI 1040 steel alloys, respectively. Their findings revealed that highest level of cutting speed and feed results in maximum flank wear.

The effect of cutting speed on surface roughness is described in Figure 6(a). Value of $\mathrm{Ra}$ decreases almost in linear way with increase in cutting speed $-\alpha$ to $+\alpha$ level i.e. from 134.55-235.45 m/min. Figure 6(b) shows minimal change in surface roughness with change in feed from $-\alpha$ to 0 : lowest to middle value $(0.03-0.1 \mathrm{~mm} / \mathrm{rev}$.). However, Ra increases sharply with further increase in feed rate from $0.1-0.17 \mathrm{~mm} / \mathrm{rev}$. Value of surface roughness increases with change in depth of cut from $0.22-0.3 \mathrm{~mm}$; however, it remains nearly constant with further increase in depth of cut as shown in Figure 6(c). Best surface finish is produced at upper level of cutting speed and lower level of feed rate and depth of cut. Thakur et al. [18] and Alok and Das [55] also observed lowest value of surface roughness corresponding to upper level of cutting speed and lower level of feed rate while turning of Inconel 718 and AISI 52100 steel alloys, respectively. Similarly, Patole and Kulkarni [34] found best surface finish at lowest feed rate and depth of cut in turning of AISI 4340 steel alloy. 


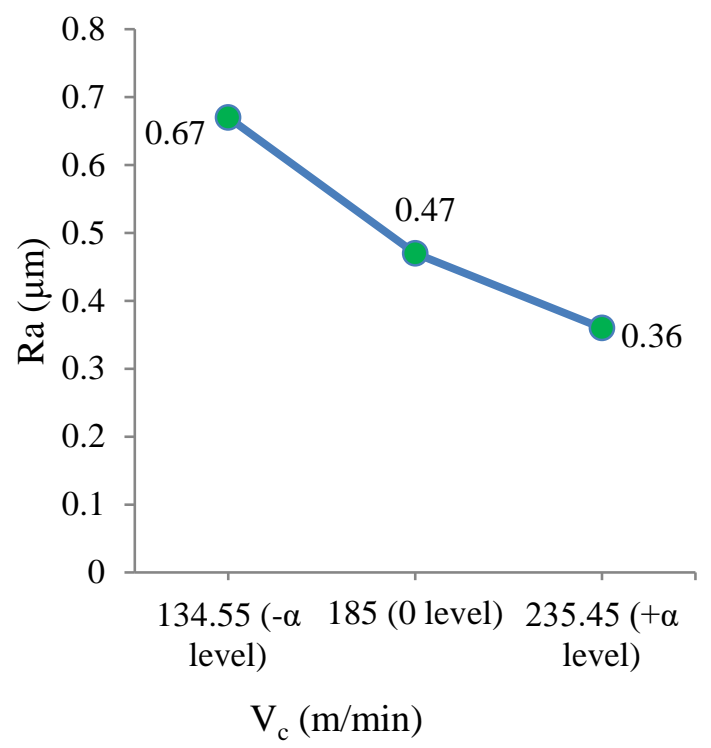

(a)

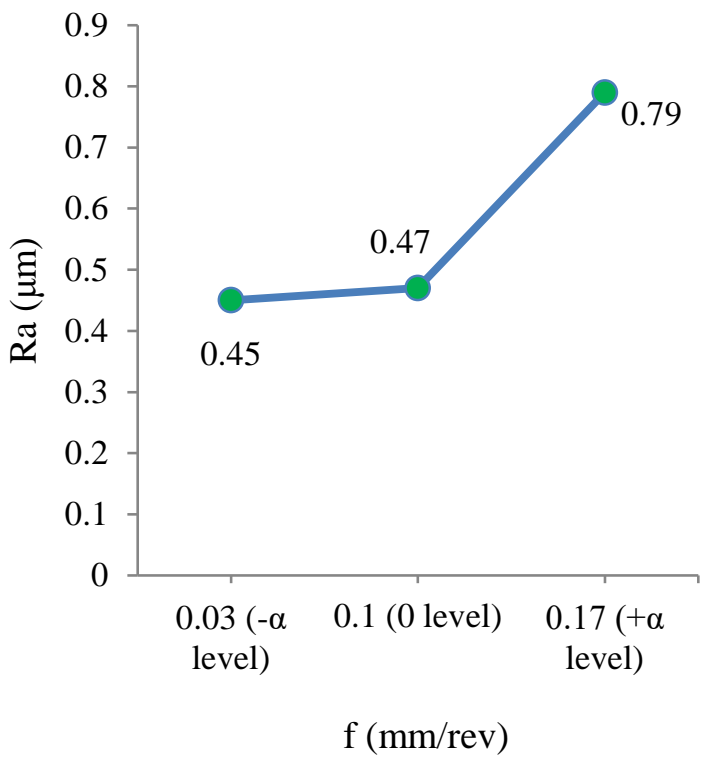

(b)

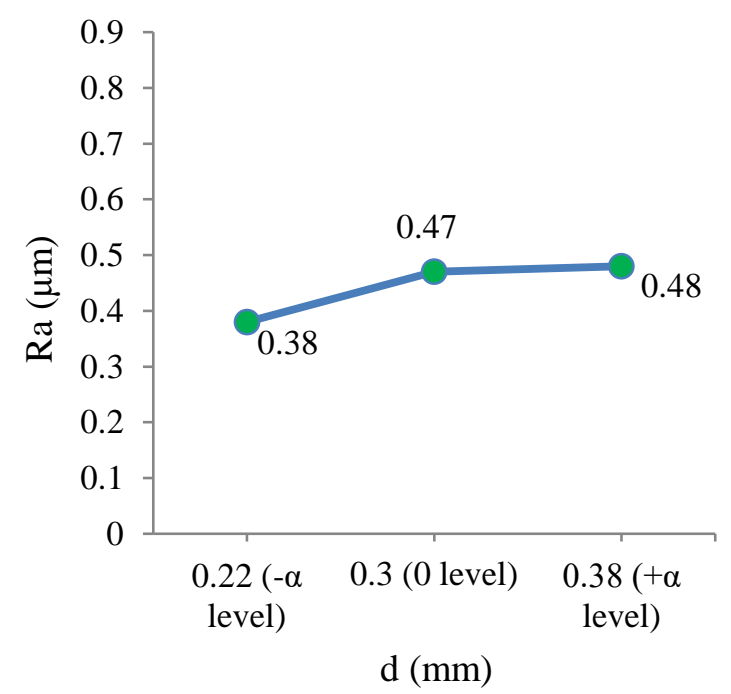

(c)

Figure 6. Effect of (a) cutting speed (at $0.1 \mathrm{~mm} / \mathrm{rev}$ feed, $0.3 \mathrm{~mm}$ depth of cut), (b) feed (at $185 \mathrm{~m} / \mathrm{min}$ cutting speed, $0.3 \mathrm{~mm}$ depth of cut) and; (c) depth of cut (at $185 \mathrm{~m} / \mathrm{min}$ cutting speed, $0.1 \mathrm{~mm} / \mathrm{rev}$ feed) on surface roughness.

\section{Optimisation of Turning Parameters}

Desirability function optimisation module of RSM was employed to attain optimal setting of turning parameters for minimum tool flank wear and surface roughness. The optimum solution was found at $160.67 \mathrm{~m} / \mathrm{min} \mathrm{V}_{\mathrm{c}}, 0.06 \mathrm{~mm} / \mathrm{rev}$ feed and $0.25 \mathrm{~mm}$ depth of cut with optimal predicted response of $100.001 \mu \mathrm{m} \mathrm{V}_{\mathrm{b}}$ and $0.509 \mu \mathrm{m}$ Ra with 0.808 desirability level. Confirmation tests (repeated thrice) were conducted with suggested optimum parameters under same NF-MQL conditions. Table 6 shows error between predicted and experimental measured values of $\mathrm{V}_{\mathrm{b}}$ and $\mathrm{Ra}$ is less than 5\%; thus all the experimental values obtained during the confirmation experiments are within the $95 \%$ prediction interval, which validates the accuracy of mathematical models developed for $\mathrm{V}_{\mathrm{b}}$ and $\mathrm{Ra}$ in this study. 
Table 6. Confirmation test results.

\begin{tabular}{lccc}
\hline \multirow{2}{*}{$\begin{array}{l}\text { Response } \\
\text { factors }\end{array}$} & \multicolumn{3}{c}{ Results obtained at optimum machining parameters } \\
& Model $(\mu \mathrm{m})$ & Experimental $(\mu \mathrm{m})$ & Error $(\%)$ \\
\hline $\mathrm{V}_{\mathrm{b}}$ & 100.001 & 103.33 & $3.22 \%$ \\
$\mathrm{Ra}$ & 0.509 & 0.527 & $3.41 \%$ \\
\hline
\end{tabular}

\section{Machining Performance under Different Turning Environments}

In second stage design, nine turning experiments were performed at an optimal setting of parameters achieved through first design stage optimisation, to evaluate turning performance under different environments viz. dry, flooded and NF-MQL. To avoid experimental error, tests were performed in random order under different cutting conditions and replicated thrice. Design layout for the second stage along with results measured for $\mathrm{V}_{\mathrm{b}}$ and $\mathrm{Ra}$ is shown in Table 7. The average measured values of tool wear and surface roughness under different cutting environments are depicted in Figure 7.

Table 7. Second stage design plan with results.

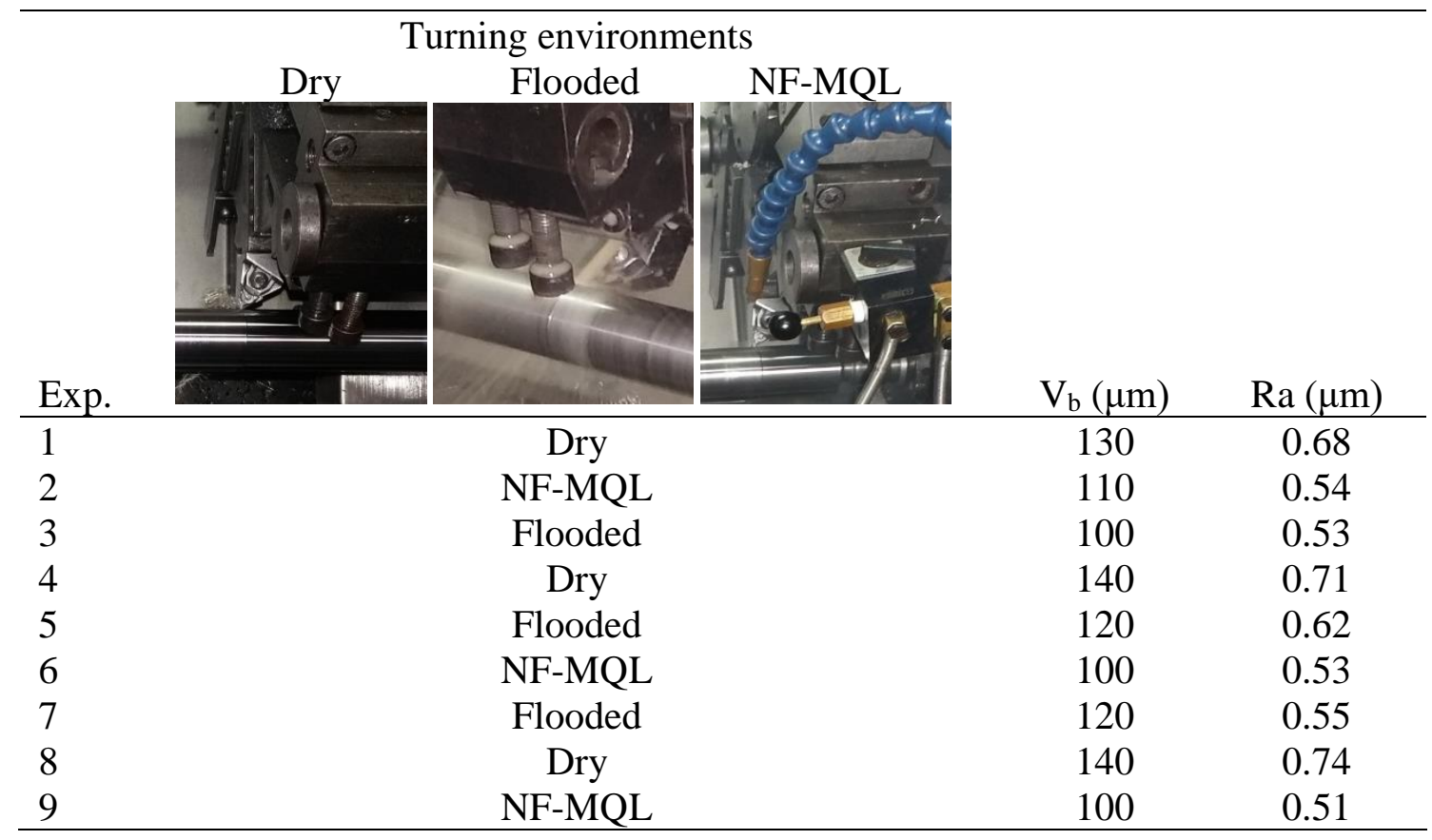

\section{Tool wear comparison}

During machining of hard-to-cut materials like AISI 304 stainless steel, interactions between cutting insert-chip-workpiece results in different modes of tool wear. Main types of wear mechanisms are classified as abrasion (thermo-dynamic wear), adhesion, diffusion (thermo-chemical wear), plastic deformation, oxidation, notching, coating delamination, edge chipping and microchipping [66, 67]. 


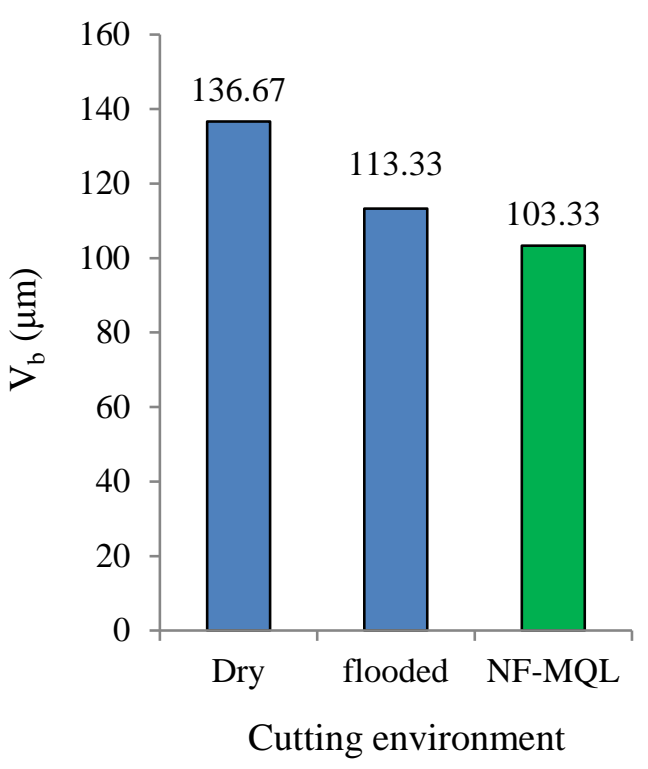

(a)

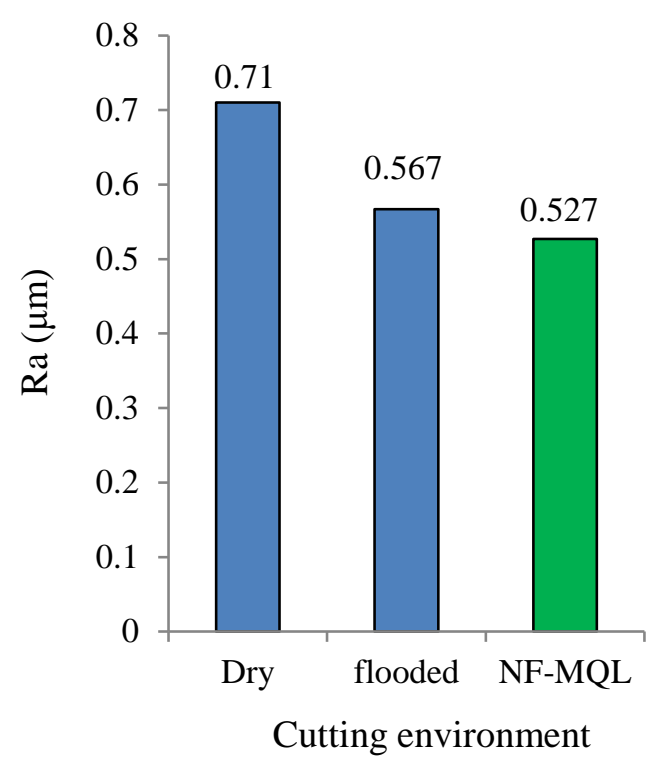

(b)

Figure 7. Machining performance under different cutting environments responding to average (a) flank wear and; (b) surface roughness.

Higher tool flank wear of $136.67 \mu \mathrm{m}$ in Figure 7(a) was noticed under dry machining environment compared to flooded and NF-MQL cooling conditions. In dry cutting, heat dissipation occurs at a very slow rate due to the absence of coolant/cutting fluid and poor thermal conductivity of AISI 304. This leads to excessive friction and higher cutting region temperature, consequently, causes severe thermal loads on the tool edge [68]. The existence of high heat at tool cutting edge for long duration results in tool material softening and coating delamination. Continuous rubbing of thermally softened tool material and machined work piece surface without lubricant/coolant under high temperature and frictional forces, produces micro-chipping and multiple edge-chipping phenomenon along with severe notching/shallow pocket of depth of $104.686 \mu \mathrm{m}$ as revealed from SEM micrograph of worn out cutting edge under dry machining conditions shown in Figure 8(a) to (c). Inclusion and movement of hard chipped material between tool and work surface create abrasion wear marks as examined in Figure 8(c).

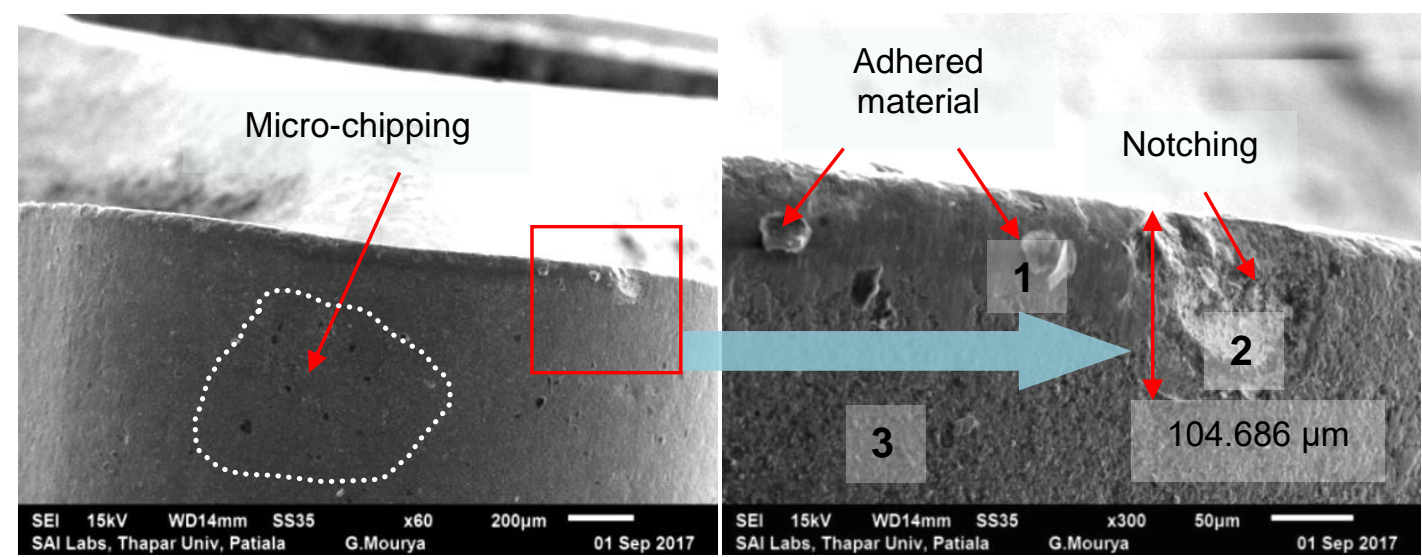

(a)

(b) 


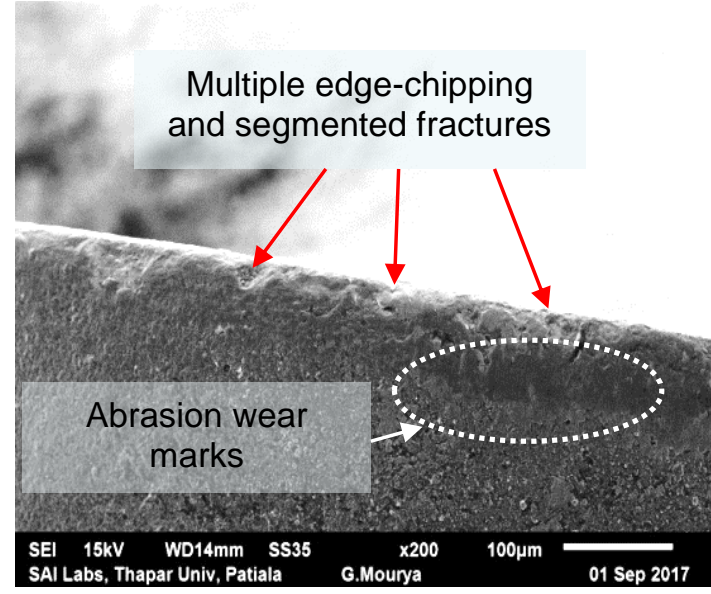

(c)

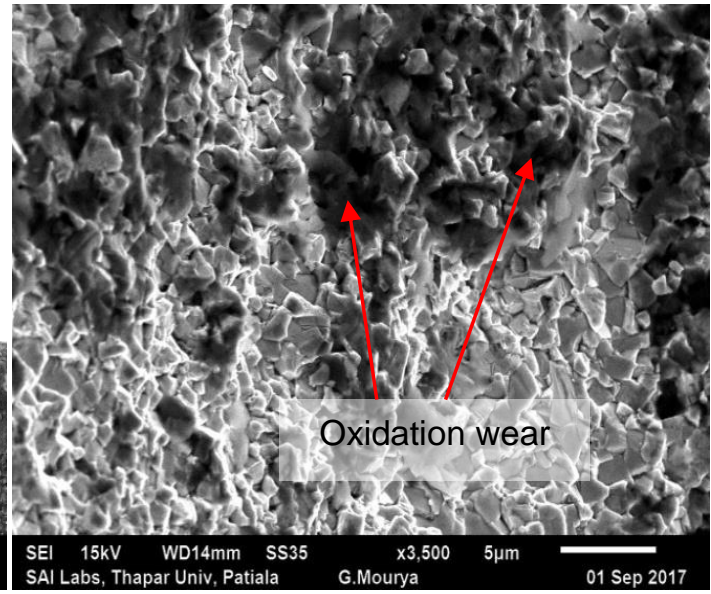

(d)

Figure 8. SEM micrographs of tool wear under dry machining conditions with the presence of (a) microchipping, (b) notching, (c) abrasion and; (d) oxidation.

Figure 9 indicates the EDAX spectrum/element analysis of cutting insert corresponding to locations marked in Figure 8(b). EDAX / element analysis at notch wear (spectrum 2) shows element from tool substrate material such as Co-6.56\% and W$58.89 \%$ and no evidence of elements from tool coating material like Al, Ti etc. Whereas, elemental analysis at location 3 confirms the existence of tool coating material viz. Al$14.98 \%$, Ti-37.52\% and N-24.04\%. This clearly illustrates that tool coating material is completely delaminated at location 2, exposing tool substrate to air and thus undergoes oxidation wear (black fraction) during dry machining process as examined in Figure 8(d). Segregated traces of adhered material were also observed on tool flank face, mainly consists of elements from tool and workpiece material viz. Fe-4.42\%, Ti-18.67\%, Al$12.21 \%$ and S-1.83\% (spectrum 1; Figure 8(b) and Figure 9). Similar wear mechanisms have also been witnessed by Pervaiz et al. [24] and Khandekar et al. [68] during dry turning of $\mathrm{Ti} 6 \mathrm{Al} 4 \mathrm{~V}$ titanium and AISI 4340 steel alloys, respectively.

In the flooded machining conditions (Coolant applied: ECOCOOL600 NBF-C; Fuchs lubricants at 0.5 bar), a lesser tool flank wear was observed in Figure 7 (a) with $V_{b}$ was $113.33 \mu \mathrm{m}$ compared to dry cutting due to lubrication and cooling ability of the cutting fluid. It was seen from SEM characterisation in Figure 10 that abrasion and adhesive wear are the prominent tool wear modes in flooded machining of AISI 304. Bulk supply of flood coolant results in quenching of work material leading to rapid work hardening that may cause abrasion wear of tool flank face as depicted in Figure 10(a). Moreover, the sticky nature of AISI 304 produces strong adhesive forces among tool and workpiece during machining. This leads to adherence to workpiece chip material on tool flank face by cold-welding phenomenon during plastic deformation in the cutting region as explained by Zhu et al. [67]. Adhered workpiece chip material in the form of a builtup layer (BUL) and built-up edge (BUE) is seen in SEM micrographs of Figure 10(b) and (c). EDAX analysis in Figure 11(a), (b) and (c) shows BUL and BUE are mainly composed of workpiece elements (Cr-17.92\% max., Ni-7.10\% max. and Fe-69.73\% $\max$.$) .$ 


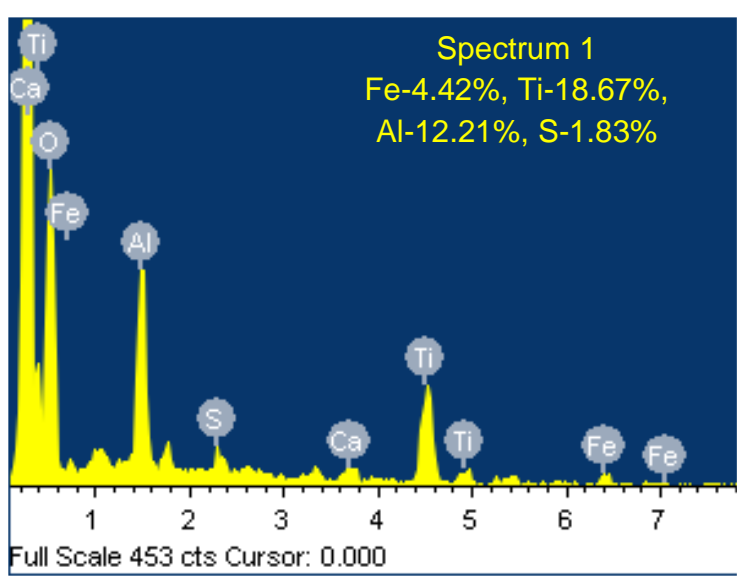

(a)

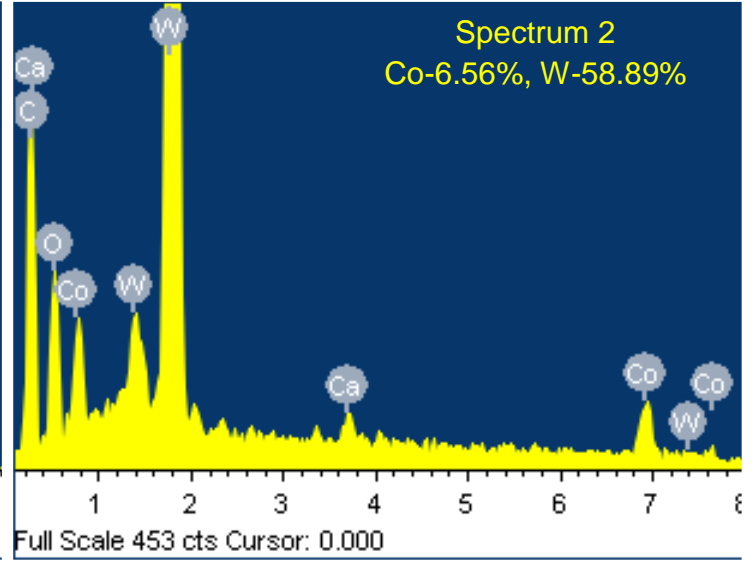

(b)

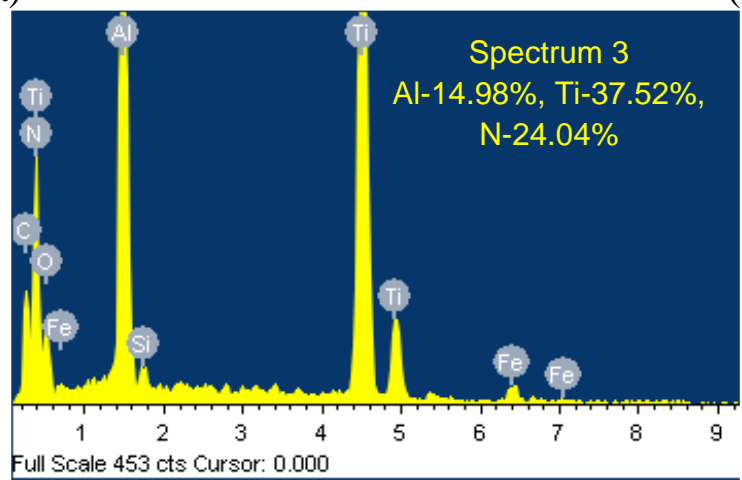

(c)

Figure 9. EDAX analysis of wear location (a) 1, (b) 2 and; (c) 3 due to dry machining conditions.

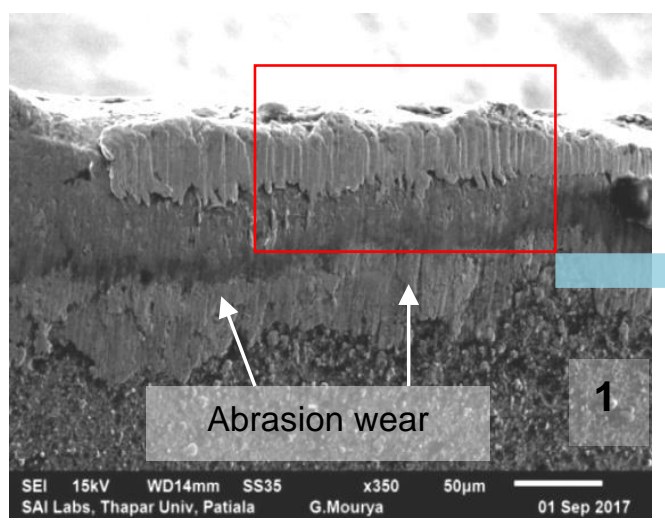

(a)

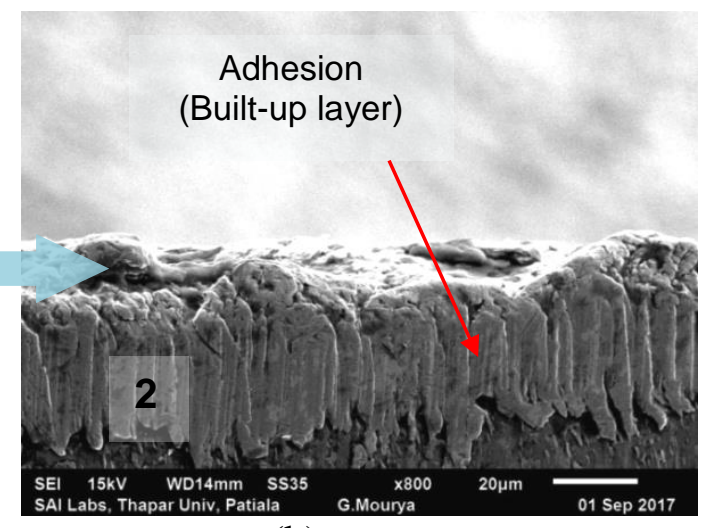

(b) 


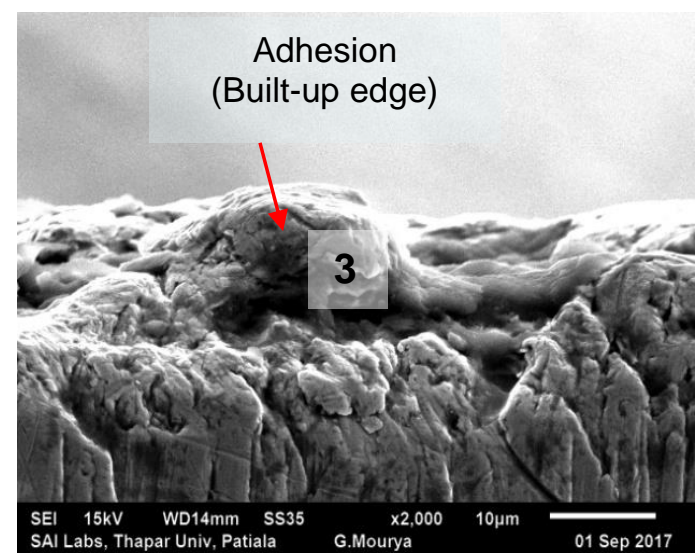

(c)

Figure 10. SEM micrographs of tool wear under flooded machining conditions with the presence of (a) abrasion wear, (b) built-up layer and; (c) built up edge.

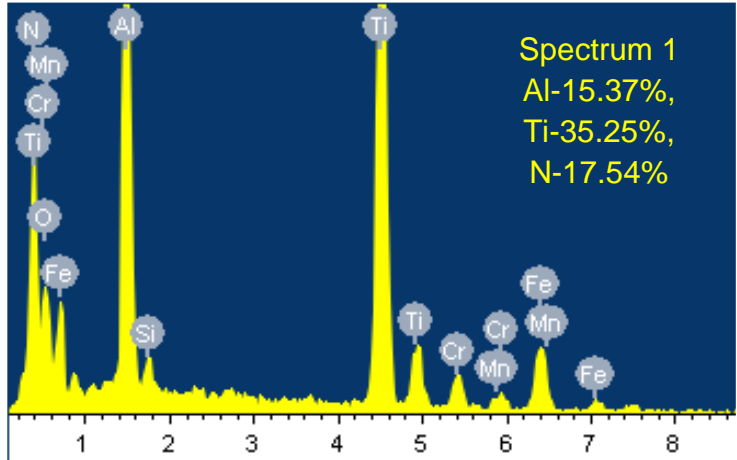

Full Scale 453 cts Cursor: 0.000

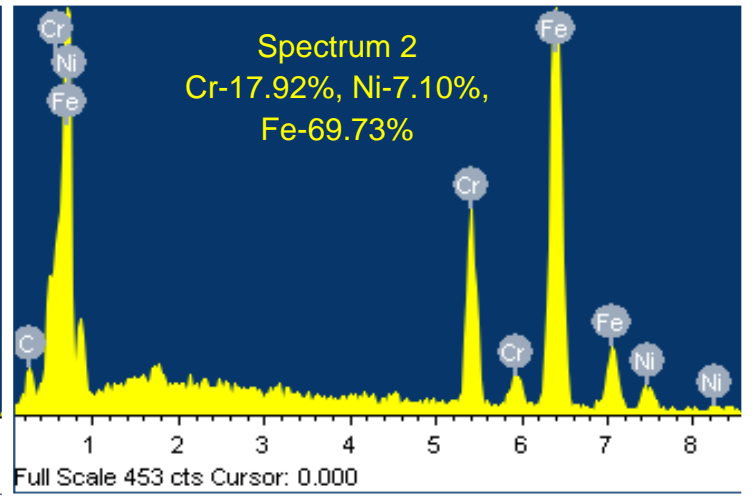

(b)

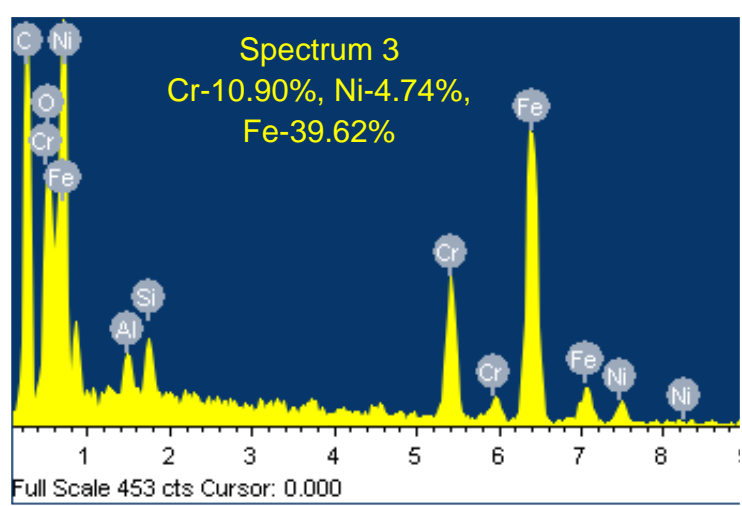

(c)

Figure 11. EDAX analysis of wear location (a) 1, (b) 2 and; (c) 3 under flooded machining conditions.

Turning of AISI 304 using soybean oil reinforced with multiwall carbon nanotubes (MWCNT) based cutting fluid under nanofluid minimum quantity lubrication (NF-MQL) resulted in minimum flank wear of $103.33 \mu \mathrm{m}$ as in Figure 7(a). SEM/EDAX images in Figure 12(a), (c) and (d) depict that abrasive and adhesion wear mechanisms were reduced significantly under NF-MQL environment compared to other cooling 
environments. EDAX analysis corresponding to location 1 in Figure 12(a) shows elements of adhered material; such as $\mathrm{Cr}-8.94 \%$, Ni-3.53\%, Fe-34.33\% are from workchip material whereas; location 2 confirms tool coating material (Al-21.44\%, Ti-53.10\%). SEM wear characterisation in Figure 12(a) reveals that the workpiece material was adhered (in small quantity) at multiple locations without resulting any built-up edge (BUE) formation, thus confirms uniform tool wear on flank face. Also, no sign of coating delamination was found under NF-MQL machining. These improved outcomes are because of the fact that high-velocity NF-MQL jet accompanied with compressed air penetrates closer and deeper in the tool-work-chip interface, resulting in effective reduction of turning zone temperature [14]. Figure 12(b) illustrates nanofluid lubrication and cooling action between cutting insert and workpiece. Nanoparticles are surrounded by thin base oil film settled as tribo-layer on the surface of cutting insert and workpiece, thus providing improved tribological behaviour and reduction of generated frictional forces during turning [69]. Also, a rolling effect caused by cylindrical nanoparticles in tool-work interface lowers friction coefficient and thereby leads to lesser cutting forces and tool wear [35].

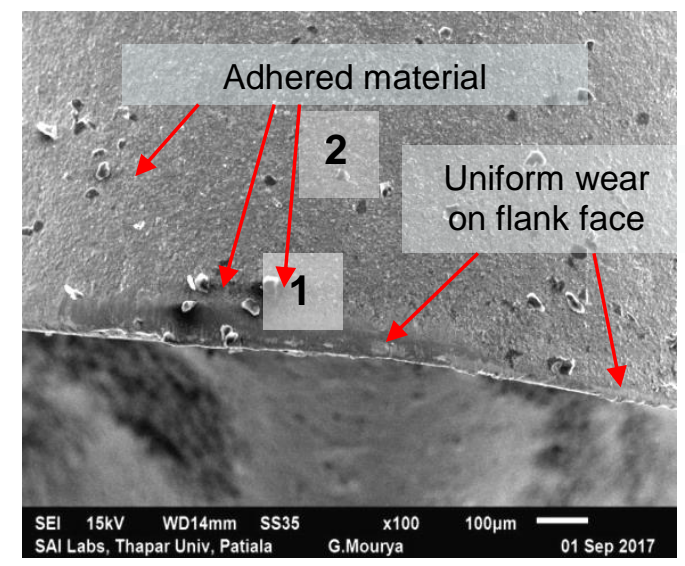

(a)

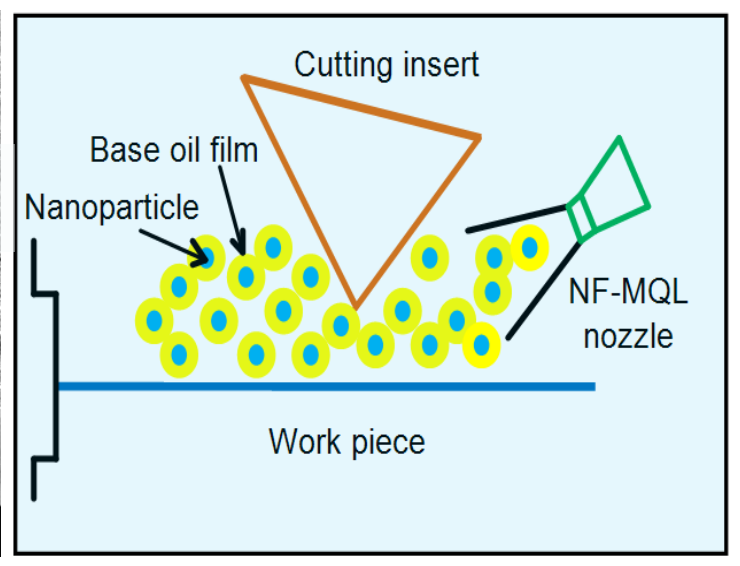

(b)

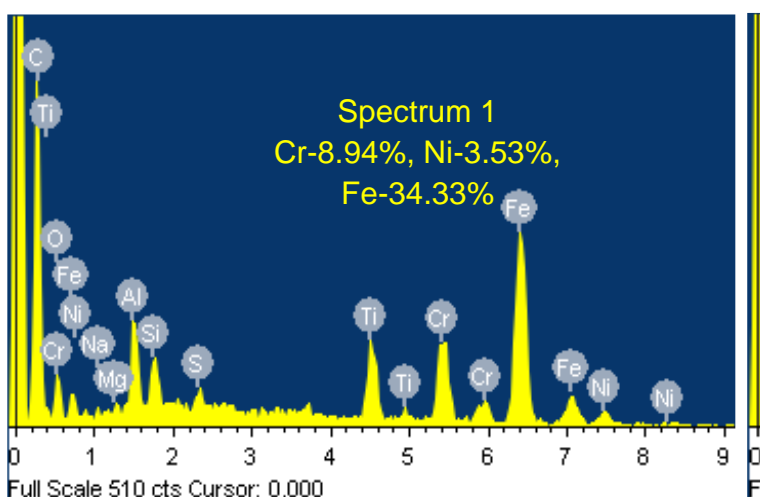

(c)

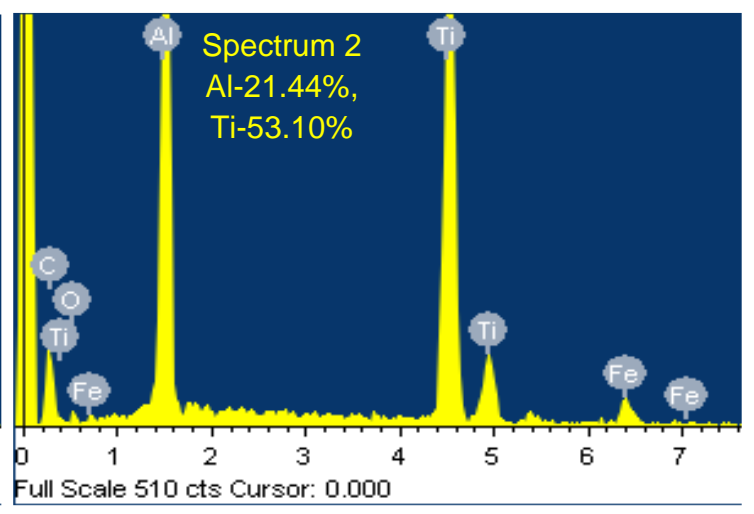

(d)

Figure 12. (a) SEM micrograph of tool wear under NF-MQL, (b) NF-MQL mechanism, EDAX analysis of location (c) 1 and; (d) 2 from micrograph (a).

Furthermore, the high thermal conductivity of MWCNT promotes heat dissipation rate from the machining zone and vapourisation of base oil absorbs a considerable amount of heat compared to conduction mode of flooded machining environment. Choi et al. [70] claimed that dispersion of $1 \%$ vol. MWCNT nanoparticles in base oil improves its thermal 
conductivity by $150 \%$. Because of the enhanced frictional and thermal characteristic in cutting zone under NF-MQL conditions, cutting tool retains its properties for a longer duration, resulting minimum flank wear compared to dry and flood coolant turning environments. Similar results were also confirmed by Amrita et al. [71] and Sahu et al. [33] in MQL turning of AISI 1040 steel and Ti-6Al-4V grade 5 titanium alloys using nanofluids. NF-MQL turning of AISI 304 shows a reduction of tool flank wear by $32.26 \%$ and $9.68 \%$ compared to dry and flooded coolant conditions, respectively.

\section{Machined surface quality}

Machined surface integrity plays a crucial role in the products/components manufactured from AISI 304 stainless steel with tight tolerances applied on product dimensions [28, 43]. Different product functional characteristics such as wear and tear resistance, fatigue resistance, friction and coating holding potential etc. are judged by its surface quality. Therefore, optimisation of cutting environments/conditions is important to attain the desired level of surface quality and dimensional accuracy of the products [24]. Figure 7(b) depicts average values of surface roughness achieved while turning of AISI 304 under different conditions. It was examined that dry turning conditions resulted in the poor surface finish $(\mathrm{Ra}=0.71 \mu \mathrm{m})$. In a dry environment, machining action is not smooth due to the absence of cutting fluid; thereby resulting in high temperature and rapid tool wear which leads to the poor machined surface. Under flooded coolant environment, lesser surface roughness $(\mathrm{Ra}=0.567 \mu \mathrm{m})$ was observed because of reduced tool flank face damage compared to dry conditions as confirmed from SEM micrographs (Figure 8 and 10). However, nano-fluid MQL turning exhibited the lowest surface roughness of $0.527 \mu \mathrm{m}$ compared to other machining environments. This is attributed to enhanced lubrication performance and better cooling ability offered by nanofluid.

Besides, the presence of nanofluid lowers friction at chip-tool-work interface which results in a reduction of tool wear and cutting zone temperature, thereby retaining tool edge hardness and sharpness. This leads to improved machined surface integrity of work material. Similar enhancement in surface quality was also investigated by Patole and Kulkarni [34], Raju et al. [31] and Sharma et al. [41] during NF-MQL turning of AISI 4340, EN 31 and AISI 1040 steel alloys, respectively. NF-MQL machining of AISI 304 shows improvement in the surface finish by $34.72 \%$ and $7.59 \%$ over dry and flooded coolant environments, respectively.

\section{CONCLUSION}

In the present work, machining performance of AISI 304 austenitic stainless steel under different turning environments is investigated using a PVD coated carbide cutting tool. The following conclusions can be drawn from this study:

i. ANOVA analysis reveals 2FI (2-factor interaction) model as the best fit model for response $V_{b}$, whereas the quadratic model is found an as best fit model for surface roughness. Results show cutting speed with feed interaction has maximum influence on tool flank wear with the percentage contribution of $61.2 \%$, followed by cutting speed of $26.9 \%$ and feed of $0.1 \%$. Whereas, the surface roughness is most sensitive to cutting speed with a percentage contribution of $28.6 \%$, followed by feed of $21.4 \%$ and depth of cut of $7.1 \%$. 
ii. Optimum turning parameters obtained through desirability function optimisation under NF-MQL conditions are at $160.67 \mathrm{~m} / \mathrm{min}$ cutting speed, $0.06 \mathrm{~mm} / \mathrm{rev}$ feed and $0.25 \mathrm{~mm}$ depth of cut with 0.808 desirability level.

iii. Results of confirmation tests show error between predicted and experimental measured values of $\mathrm{V}_{\mathrm{b}}$ and $\mathrm{Ra}$ is less than $5 \%$. Thus all the experimental values obtained during the confirmation experiments are within the $95 \%$ prediction interval, which clearly validates the accuracy of mathematical models developed for $\mathrm{V}_{\mathrm{b}}$ and $\mathrm{Ra}$ in this study.

iv. SEM wear characterisation reveals micro-chipping, multiple edge-chipping, abrasion, adhesive, oxidation and severe notching as main wear modes under dry turning, whereas abrasion and adhesion wear with BUL and BUE are the prominent wear modes in flooded machining conditions. However, turning under NF-MQL environment results in uniform wear with lesser adhesion compared to other machining environments.

v. Present work establishes the superiority of NF-MQL over dry and flooded coolant conditions. Machining of AISI 304 under NF-MQL environment shows a reduction of tool flank wear by $32.26 \%$ and $9.68 \%$ compared to dry and flooded coolant conditions, respectively. Similarly, NF-MQL machining provides an improvement in the surface finish by $34.72 \%$ and $7.59 \%$ over dry and flooded coolant environments, respectively.

vi. The encouraging results of NF-MQL technique provide a viable base for sustainable manufacturing, particularly in machining of hard-to-cut materials such as AISI 304 stainless steel, by giving enhanced tool life and better surface finish. Moreover, NF-MQL provides clean, environment-friendly and dry work area.

The present study employs external spray of nanofluid based on MWCNT nanoparticles in the cutting zone through a nozzle using compressed air. The future research work can be extended to explore the possibilities of internal NF-MQL supply system through a cutting tool or tool holder in turning applications. Suitability of hybrid nanofluids in NF-MQL technique can be investigated in future.

\section{REFERENCES}

[1] Mahdavinejad RA, Saeedy S. Investigation of the influential parameters of machining of AISI 304 stainless steel. Sadhana 2011; 36(6): 963-970.

[2] Nayak SK, Patro JK, Dewangan S, Gangopadhyay S. Multi-objective optimization of machining parameters during dry turning of AISI 304 austenitic stainless steel using grey relational analysis. Procedia Materials Science 2014; 6: 701-708.

[3] Çaydaş U, Ekici S. Support vector machines models for surface roughness prediction in CNC turning of AISI 304 austenitic stainless steel. Journal of Intelligent Manufacturing 2012; 23(3): 639-650.

[4] Korkut I, Kasap M, Ciftci I, Seker U. Determination of optimum cutting parameters during machining of AISI 304 austenitic stainless steel. Materials \& Design 2004; 25(4): 303-305.

[5] M'Saoubi R, Outeiro JC, Chandrasekaran H, Dillon Jr OW, Jawahir IS. A review of surface integrity in machining and its impact on functional performance and life of machined products. International Journal of Sustainable Manufacturing 2008; 1(1-2): 203-236. 
[6] Colak O. Investigation on machining performance of Inconel 718 in high pressure cooling conditions. Journal of Mechanical Engineering 2012; 58(11): 683-690.

[7] Singh T, Singh P, Dureja JS, Dogra M, Singh H, Bhatti MS. A review of near dry machining / minimum quantity lubrication machining of difficult to machine alloys. International Journal of Machining and Machinability of Materials 2016; 18(3): 213-251.

[8] Cetin MH, Ozcelik B, Kuram E, Demirbas E. Evaluation of vegetable based cutting fluids with extreme pressure and cutting parameters in turning of AISI 304L by Taguchi method. Journal of Cleaner Production 2011; 19(17-18): 20492056.

[9] Ali MAM, Khalil ANM, Azmi AI, Salleh HM. Optimization of cutting parameters for surface roughness under MQL, using $\mathrm{Al}_{2} \mathrm{O}_{3}$ nanolubricant, during Turning of Inconel 718. IOP Conf Series: Materials Science and Engineering 2017; 226: 1-7.

[10] Adler DP, Hii WW-S, Michalek DJ, Sutherland JW. Examining the role of cutting fluids in machining and efforts to address associated environmental/health concerns. Machining Science and Technology 2006; 10(1): 23-58.

[11] Dhar NR, Kamruzzaman M, Ahmed M. Effect of minimum quantity lubrication (MQL) on tool wear and surface roughness in turning AISI-4340 steel. Journal of Materials Processing Technology 2006; 172(2): 229-304.

[12] Xavior MA, Adithan M. Determining the influence of cutting fluids on tool wear and surface roughness during turning of AISI 304 austenitic stainless steel. Journal of Materials Processing Technology 2009; 209(2): 900-909.

[13] Hong S, Broomer M. Economical and ecological cryogenic machining of AISI 304 austenitic stainless steel. Clean Products and Processes 2000; 2(3): 157-166.

[14] Yazid MZA, CheHaron CH, Ghani JA, Ibrahim GA, Said, AYM. Surface integrity of Inconel 718 when finish turning with PVD coated carbide tool under MQL. Procedia Engineering 2011; 19: 396-401.

[15] Davim JP, Sreejith PS, Silva J. Turning of brasses using minimum quantity of lubricant (MQL) and flooded lubricant conditions. Journal of Materials and Manufacturing Processes 2007; 22(1): 45-50.

[16] Sharma AK, Tiwari AK, Dixit AR. Effects of minimum quantity lubrication (MQL) in machining processes using conventional and nanofluid based cutting fluids- A comprehensive review. Journal of Cleaner Production 2016; 127: 1-18.

[17] Singh T, Dureja JS, Dogra M, Bhatti MS. Environment friendly machining of Inconel 625 under nano-fluid minimum quantity lubrication (NMQL). International Journal of Precision Engineering and Manufacturing 2018; 19(11): 1689-1697.

[18] Thakur DG, Ramamoorthy B, Vijayaraghavan L. Influence of minimum quantity lubrication on the high speed turning of aerospace material superalloy Inconel 718. International Journal of Machining and Machinability of Materials 2013; 13(2-3): 203-214.

[19] Singh T, Dureja JS, Dogra M, Bhatti MS. Dry turning of superalloy Inconel 625 using refrigerated cooled-air jet. International Journal of Emerging Technologies and Innovative Research 2018; 5(10): 391-398.

[20] Asiltürk İ, Neşeli S. Multi response optimisation of CNC turning parameters via Taguchi method-based response surface analysis. Measurement 2012; 45(4): 785794. 
[21] Sharma Vishal S, Dogra M, Suri NM. Cooling techniques for improved productivity in turning. International Journal of Machine Tools and Manufacture 2009; 49(6): 435-453.

[22] Rahim EA, Ibrahim MR, Rahim AA, Aziz S, Mohid Z. Experimental Investigation of Minimum Quantity Lubrication (MQL) as a Sustainable Cooling Technique. Procedia CIRP 2015; 26: 351-354.

[23] Gupta MK, Sood PK. Machining comparison of aerospace materials considering minimum quantity cutting fluid: A clean and green approach. Proc. IMechE. Part C: Journal of Mechanical Engineering Science 2017; 231(8): 1445-1464.

[24] Pervaiz S, Deiab I, Rashid A, Nicolescu M. Minimal quantity cooling lubrication in turning of Ti6Al4V: Influence on surface roughness, cutting force and tool wear. Proc. IMechE. Part B: Journal of Engineering Manufacture 2015; 231(9): 1542-1558.

[25] Maruda RW, Krolczyk GM, Wojciechowski S, Zak K, Habrat W, Nieslony P. Effects of extreme pressure and anti-wear additives on surface topography and tool wear during MQCL turning of AISI 1045 steel. Journal of Mechanical Science and Technology 2018; 32(4): 1585-1591.

[26] Maruda RW, Krolczyk GM, Niesłony P, Krolczyk JB, Legutko, S. Chip formation zone analysis during the turning of austenitic stainless steel $316 \mathrm{~L}$ under MQCL Cooling Condition. Procedia Engineering 2016; 149: 297-304.

[27] Park KH, Yang GD, Lee MG, Jeong H, Lee SW, Lee DY. Eco-friendly face milling of titanium alloy. International Journal of Precision Engineering and Manufacturing 2014; 15(6): 1159-1164.

[28] Pusavec F, Hamdi H, Kopac J, Jawahir IS. Surface integrity in cryogenic machining of nickel-based alloy-Inconel 718. Journal of Materials Processing Technology 2011; 211(4): 773-783.

[29] Varadarajan AS, Philip PK, Ramamoorthy B. Investigations on hard turning with minimal cutting fluid application (HTMF) and its comparison with dry and wet turning. International Journal of Machine Tools and Manufacture 2002; 42(2): 193-200.

[30] Srikant RR, Prasad MMS, Amrita M, Sitaramaraju AV, Vamsi Krishna P. Nanofluids as a potential solution for Minimum Quantity Lubrication - A review. Proc IMechE Part B: Journal of Engineering Manufacture 2013; 228(1): 3-20.

[31] Raju RA, Andhare A, Sahu NK. Performance of multi-walled carbon nanotubebased nanofluid in turning operation. Journal of Materials and Manufacturing Processes 2017; 32(13): 1490-1496.

[32] Minh DT, The LT, Bao NT. Performance of $\mathrm{Al}_{2} \mathrm{O}_{3}$ nanofluids in minimum quantity lubrication in hard milling of $60 \mathrm{Si}_{2} \mathrm{Mn}$ steel using cemented carbide tools. Advances in Mechanical Engineering 2017; 9(7): 1-9.

[33] Sahu NK, Andhare AB, Raju RA. Evaluation of performance of nanofluid using multiwalled carbon nanotubes for machining of Ti-6AL-4V. Machining Science and Technology 2018; 22(3): 476-492.

[34] Patole PB, Kulkarni VV. Optimization of process parameters based on surface roughness and cutting force in MQL turning of AISI 4340 using nano fluid. Materials Today: Proceedings 2018; 5(1): 104-112.

[35] Hegab H, Umer U, Deiab I, Kishawy H. Performance evaluation of Ti-6Al-4V machining using nano-cutting fluids under minimum quantity lubrication. International Journal of Advanced Manufacturing Technology 2018; 95(9-12): $4229-4241$. 
[36] Mao C, Huang Y, Zhou X, Gan H, Zhang J, Zhou Z. The tribological properties of nanofluid used in minimum quantity lubrication grinding. International Journal of Advanced Manufacturing Technology 2014; 71(5-8): 1221-1228.

[37] Uysal A, Demiren F, Altan E. Applying minimum quantity lubrication (MQL) method on milling of martensitic stainless steel by using nano $\mathrm{MoS}_{2}$ reinforced vegetable cutting fluid. Procedia - Social and Behavioral Sciences 2015; 195: 2742-2747.

[38] Nam JS, Lee PH, Lee SW. Experimental characterization of micro-drilling process using nanofluid minimum quantity lubrication. International Journal of Machine Tools and Manufacture 2011; 51(7-8): 649-652.

[39] Krishna PV, Srikant RR, Rao DN. Experimental investigation on the performance of nanoboric acid suspensions in SAE-40 and coconut oil during turning of AISI 1040 steel. International Journal of Machine Tools and Manufacture 2010; 50(10): 911-916.

[40] Khan A, Maity K. Influence of cutting speed and cooling method on the machinability of commercially pure titanium (CP-Ti) grade II. Journal of Manufacturing Processes 2018; 31: 650-661.

[41] Sharma AK, Tiwari AK, Singh RK, Dixit AR. Tribological investigation of $\mathrm{TiO}_{2}$ nanoparticle based cutting fluid in machining under minimum quantity lubrication (MQL). Materials Today: Proceedings 2016; 3(6): 2155-2162.

[42] Sharma J, Sidhu BS. Investigation of effects of dry and near dry machining on AISI D2 steel using vegetable oil. Journal of Cleaner Production 2014; 66: 619623.

[43] Khan MMA, Mithu MAH, Dhar NR. Effects of minimum quantity lubrication on turning AISI 9310 alloy steel using vegetable oil-based cutting fluid. Journal of Materials Processing Technology 2009; 209(15-16): 5573-5583.

[44] Lawal SA, Choudhury IA, Nukman Y. Evaluation of vegetable and mineral oilin-water emulsion cutting fluids in turning AISI 4340 steel with coated carbide tools. Journal of Cleaner Production 2014; 66: 610-618.

[45] Devillez A, Le Coz G, Dominiak S, Dudzinski D. Dry machining of Inconel 718, workpiece surface integrity. Journal of Materials Processing Technology 2011; 211(10): 1590-1598.

[46] Noordin MY, Venkatesh VC, Sharif S. Dry turning of tempered martensitic stainless tool steel using coated cermet and coated carbide tools. Journal of Materials Processing Technology 2007; 185(1-3): 83-90.

[47] Ginting A, Nouari M. Surface integrity of dry machined titanium alloys. International Journal of Machine Tools and Manufacture 2009; 49(3-4): 325332.

[48] Nouari M, List G, Girot F, Géhin D. Effect of machining parameters and coating on wear mechanisms in dry drilling of aluminium alloys. International Journal of Machine Tools and Manufacture 2005; 45(12-13): 1436-1442.

[49] Alok A, Das M. Cost-effective way of hard turning with newly developed HSN $^{2}$-coated tool. Materials and Manufacturing Processes 2018; 33(9): 10031010.

[50] Fukui H, Okida J, Omori N, Moriguchi H, Tsuda K. Cutting performance of DLC coated tools in dry machining aluminum alloys. Surface and Coatings Technology 2004; 187(1): 70-76.

[51] Mia M, Dhar NR. Optimization of surface roughness and cutting temperature in high-pressure coolant-assisted hard turning using Taguchi method. The 
International Journal of Advanced Manufacturing Technology 2017; 88(1-4): 739-753.

[52] Makadia AJ, Nanavati JI. Optimisation of machining parameters for turning operations based on response surface methodology. Measurement 2013; 46(4): 1521-1529.

[53] Sarikaya M, Güllü A. Taguchi design and response surface methodology based analysis of machining parameters in CNC turning under MQL. Journal of Cleaner Production 2014; 65: 604-616.

[54] Mia M. Mathematical modeling and optimization of MQL assisted end milling characteristics based on RSM and Taguchi method. Measurement 2018; 121: 249-260.

[55] Alok A, Das M. Multi-objective optimization of cutting parameters during sustainable dry hard turning of AISI 52100 steel with newly develop $\mathrm{HSN}^{2}$ coated carbide insert. Measurement 2019; 133: 288-302.

[56] Rabiei F, Rahimi AR, Hadad MJ, Ashrafijou M. Performance improvement of minimum quantity lubrication (MQL) technique in surface grinding by modeling and optimization. Journal of Cleaner Production 2015; 86: 447-460.

[57] Tools news B036G. Mitsubishi Materials Corporation. Retrieved from http://www.mitsubishicarbide.com/application/files/8314/4643/8969/b036g.pdf; 15 January, 2018.

[58] Shashidhara YM, Jayaram SR. Vegetable oils as a potential cutting fluid- An evolution. Tribology International 2010; 43(5-6): 1073-1081.

[59] Lawal SA, Choudhury IA, Nukman Y. Application of vegetable oil-based metalworking fluids in machining ferrous metals-A review. International Journal of Machine Tools and Manufacture 2012; 52(1): 1-12.

[60] Chetan, Behera BC, Ghosh S, Rao PV. Application of nanofluids during minimum quantity lubrication-A case study in turning process. Tribology International 2016; 101: 234-246.

[61] Product information Multiwall Carbon Nanotubes. Ad-Nano Technologies Private limited. Retrieved from https://www.ad-nanotech.com/hydroxylmultiwall-carbon-nanotubes.html; 10 December, 2017.

[62] Zhang X, Zhou WX, Chen XK, Liu YY, Chen KQ. Significant decrease in thermal conductivity of multi-walled carbon nanotube induced by inter-wall vander Waals interactions. Physics Letters A 2016; 380(21): 1861-1864.

[63] Kulkarni AP, Sargade VG. Characterization and Performance of AlTiN, AlTiCrN, TiN/TiAlN PVD Coated Carbide Tools While Turning SS 304. Materials and Manufacturing Processes 2015; 30(6): 748-755.

[64] General catalogue C007B. Mitsubishi Materials Corporation. Retrieved from http://www.mitsubishicarbide.com/application/files/6114/5698/5115/catalog_c0 07b_full.pdf; 15 January, 2018.

[65] Ciftci I. Machining of austenitic stainless steels using CVD multi-layer coated cemented carbide tools. Tribology International 2006; 39(6): 565-569.

[66] Pervaiz S, Deiab I, Darras B. Power consumption and tool wear assessment when machining titanium alloys. International Journal of Precision Engineering and Manufacturing 2013; 14(6): 925-936.

[67] Zhu D, Zhang X, Ding H. Tool wear characteristics in machining of nickel-based superalloys. International Journal of Machine Tools and Manufacture 2013; 64: 60-77. 
[68] Khandekar S, Sankar MR, Agnihotri V Ramkumar J. Nano-cutting fluid for enhancement of metal cutting performance. Materials and Manufacturing Processes 2012; 27(9): 963-967.

[69] Hegab H, Umer U, Soliman M, Kishawy HA. Effects of nano-cutting fluids on tool performance and chip morphology during machining Inconel 718. International Journal of Advanced Manufacturing Technology 2018; 96(9-12): 3449-3458.

[70] Choi SUS, Zhang ZG, Yu W, Lockwood FE, Grulke EA. Anomalous thermal conductivity enhancement in nanotube suspensions. Applied Physics Letters, 2001; 79(14): 2252-2254.

[71] Amrita M, Srikant RR, Sitaramaraju AV. Performance Evaluation of nanographite-based cutting fluid in machining process. Materials and Manufacturing Processes 2014; 29(5): 600-605. 